\title{
Zooplankton diversity of a subtropical reservoir of Meghalaya, northeast India with remarks on spatial and temporal variations
}

\author{
B.K. SHARMA ${ }^{1 *} \&$ S. SHARMA ${ }^{2}$ \\ ${ }^{1}$ Bhushan Kumar Sharma, Department of Zoology, North-Eastern Hill University, Shillong - 793 022, Meghalaya, India. \\ E-mail: profbksharma@gmail.com. "Corresponding author \\ ${ }^{2}$ Sumita Sharma, Lady Veronica Road, Laitumukhrah, Shillong - 793 003, Meghalaya, India. E-mail: \\ sumitasharma.nehu@gmail.com.
}

\begin{abstract}
Nongmahir reservoir of Meghalaya state of northeast India (NEI), sampled at the littoral and limnetic regions, revealed fairly biodiverse zooplankton of total 56 species with peak consortium ( 52 species) in January collection from the littoral region. The richness indicated spatial monthly variations and heterogeneity at the two regions mainly influenced by Rotifera. The 'soft and de-mineralized waters' resulted in low zooplankton abundance. Copepoda $>$ Rotifera with Cyclopidae $>$ Brachionidae influenced zooplankton, and Mesocyclops leuckarti $>$ Keratella cochlearis $>$ Ascomorpha ovalis $>$ Microcyclops hyalinus are notable species at the littoral region. The limnetic region recorded Rotifera dominance, and importance of Brachionidae $>$ Cyclopidae and K. cochlearis $>$ Conochilus unicornis $>$ M. leuckarti $>$ A. ovalis $>$ Asplanchna priodonta $>$ Polyarthra vulgaris. Zooplankton recorded moderate species diversity and notable differences of evenness and dominance. The spatial monthly differences of richness, abundance and diversity indices of zooplankton, and importance of notable taxa are hypothesised to habitat heterogeneity of the two regions. Our results also indicated limited and differential influence of individual abiotic factors on zooplankton taxa, while the canonical correspondence analysis registered high cumulative influence of 10 abiotic factors on the littoral (80.62\%) and limnetic (74.79\%) assemblages along axis 1 and 2. This study highlighted distinct temporal variations of different diversity parameters than our preliminary survey of June 1995-May 1996.
\end{abstract}

Keywords. Composition, richness, abundance, diversity indices, demineralized, soft-water.

\section{INTRODUCTION}

Z ooplankton, an integral part of aquatic foodwebs and important fish-food organisms, has been studied from diverse aquatic biotopes since inception of the Indian limnology but received relatively less attention from lakes and reservoirs (Jana 1998). This generalization holds valid the current status of lacustrine limnology of India and that of north India in particular because of sizeable number of 'routine' ecology reports with incomplete species lists, unidentified species and inadequate data-analysis (Sharma \& Pachuau 2013). However, certain meaningful studies on zooplankton assemblages from the sub-tropical regions of India are those of Sharma and Pant (1984, 1985), Raina \& Vass (1993), Mishra et al. (2010), Ahangar et al. (2012), Jindal \& Thakur (2013), Slathia \& Dutta (2013), Thakur et al.
(2013), Malik \& Panwar (2016), Sharma \& Kumari (2018) and Singh \& Sharma (2020). The related works of Sharma \& Hussain (2001), Sharma (2011a, 2011b), Sharma \& Sharma (2008, 2011, 2012), Sharma \& Hatimuria (2017) and Sharma \& Noroh (2020) dealt with zooplankton of the floodplain lakes of NEI. However, the studies on zooplankton diversity from reservoirs of NEI are limited till date to 'ad-hoc' reports from Gumti reservoir of Tripura (Bhattacharya \& Saha 1986, 1990), and the preliminary surveys of the subtropical reservoirs from Meghalaya (Sharma 1995, Sharma and Lyngskor 2003, Sharma \& Lyngdoh 2004) and Mizoram (Sharma \& Pachuau 2013).

The present study, a follow-up of our limited survey of June 1995 - May 1996 (Sharma and Lyngskor 2003), undertaken to provide detailed 
information on zooplankton diversity of a subtropical reservoir of Meghalaya, assumes limnological interest in light of the stated lacunae. It is based on analyses of monthly littoral and limnetic net plankton collections with reference to species composition, richness, community similarities, abundance, species diversity, dominance and evenness, and individual and cumulative influence of abiotic factors on zooplankton assemblages. The results are compared with the related studies from the sub-tropical lakes of the Himalayan and subHimalayan regions of north India, the floodplain lakes and the sub-tropical environs of NEI, lacustrine ecosystems elsewhere from India and certain reports from adjacent countries of the Indian subregion. We attempt to highlight spatial variations of different aspects of diversity based on our studies at the littoral and the limnetic regions, and temporal variations in comparison with the earlier survey of June 1995 - May 1996.

\section{MATERIALS AND METHODS}

The study is based on limnological survey ( January - December, 2015) of Nongmahir reservoir $\left(25.7876^{\circ} \mathrm{N} ; 91.8251^{\circ} \mathrm{E}\right.$; area: 70 ha; maximum depth: $25 \mathrm{~m}$ ) located in Ri-Bhoi district (Fig. 1AB), at a distance of about $45 \mathrm{~km}$. from Shillong city - the capital of Meghalaya state of NEI. Nongmahir was commissioned in 1979 to serve as a pick up reservoir (Stage III) of the Umiam-Umtru hydroelectric project. This reservoir lacks any a quatic vegetation. Catla catla, Cirrhinus mrigala, Cyprinus carpio, Clarias batrachus, Dania rerio, D. acquipinnatus, D. dangila, Heteropneustes fossilis, Labeo rohita, Neolissocheilus hexagonolepis, Puntius sophore and Tor putitora are the fish species known to inhabit this reservoir.

Water samples were collected monthly from the littoral and limnetic regions. Water temperature was recorded with a centigrade thermometer, transparency with Secchi disc, $\mathrm{pH}$ and specific conductivity with the field probes, dissolved oxygen by the modified Winkler's method, and other abiotic factors: total alkalinity, total hardness, calcium, magnesium, chloride, dissolved organic matter, phosphate, nitrate and sulphate were analyzed following APHA (1992). Rainfall data was obtained from the local meteorological station. The qualitative net plankton samples collected from the two regions by towing nylobolt plankton net (mesh size: $40 \mu \mathrm{m}$ ) were preserved in $5 \%$ formalin. All the collections were screened with a Wild Stereoscopic binocular microscope, zooplankton were isolated and mounted in polyvinyl alcohol-lactophenol mixture, and were observed with Leica stereoscopic microscope (DM 1000). The species were identified following Michael \& Sharma (1988), Sharma (1983, 1998), Sharma and Sharma (1999a, 1999b, 2008). The community similarities were calculated vide Sørensen's index and the hierarchical cluster analysis using SPSS (version 20).

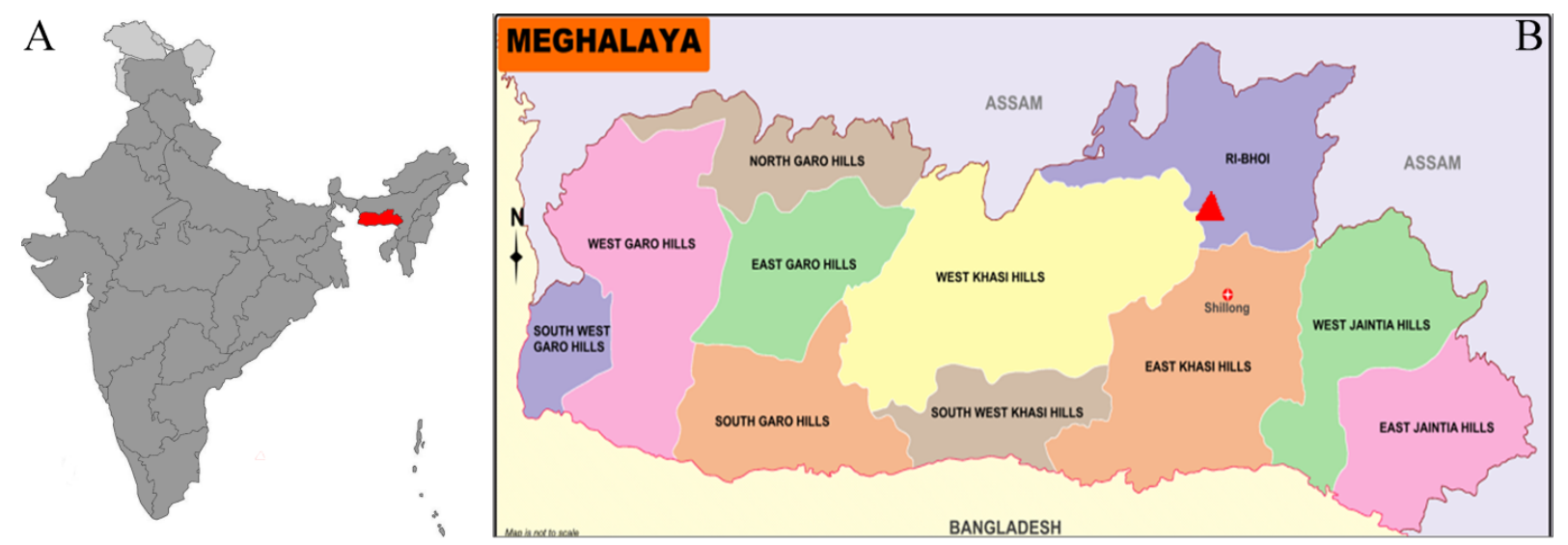

Figure 1. $A$ = map of India showing Meghalaya state (red color), $B$ = District map of Meghalaya showing Nongmahir reservoir (red triangle) in Ri-Bhoi district. 
The monthly quantitative net plankton samples were obtained by filtering $25 \mathrm{~L}$ of water each from the littoral and limnetic regions through nylobolt plankton net and were preserved in 5\% formalin. Quantitative enumeration of zooplankton assemblages was done with a SedgewickRafter counting cell and abundance was expressed as ind. $1^{-1}$ as well as ranges and means \pm S.D. Species diversity (Shannon-Weiner index), dominance (Berger-Parker index) and evenness $\left(\mathrm{E}_{1}\right.$ index) were calculated following Ludwig \& Reynolds (1988) and Magurran (1988). The significance of variations of the different abiotic and biotic factors between the sampled regions and months was ascertained by two-way ANOVA. Pearson's correlation coefficients were calculated between abiotic and biotic parameters for the littoral and limnetic regions $\left(r_{1}\right.$ and $r_{2}$, respectively), $\mathrm{p}$ values (2-tailed) were calculated vide http://vassarstats.net/tabs.html and their significance were ascertained after applying Bonferroni corrections. The canonical correspondence analysis (CCA) was done using XLSTAT (2015) to observe cumulative influence of ten abiotic parameters (for limitations of the sampled months) namely water temperature, rainfall, transparency, $\mathrm{pH}$, specific conductivity, dissolved oxygen, free carbon dioxide, total alkalinity, total hardness and chloride on zooplankton and important taxa. The study period is divided into winter (DecemberFebruary), spring (March), pre-monsoon (AprilJune), monsoon (July-October) and autumn (November) seasons for better explanation of our results; NEI experiences extended rainfall from pre-monsoon to monsoon seasons, and pre-monsoon equates with summer season elsewhere in India.

\section{RESULTS}

The variations of abiotic and biotic factors at the littoral and limnetic regions noted vide this study as well as June 1995 - May 1996 survey are presented in Tables 1-2.

We recorded total 56 species of zooplankton with 56 and 41 species recorded from the two regions, respectively of Nongmahir reservoir;
Rotifera; Cladocera, Rhizopoda, Copepoda and Ostracoda indicated 32, 10, 9, 4 and 1 species, respectively (Table 2). The monthly zooplankton richness ranged between 27-52 and 19-32 species and registered $57.6-85.7 \%$ and $51.1-88.9 \%$ community similarities, and Rotifera richness varied between 13-31 and 10-17 species, at the two regions, respectively. The hierarchical cluster analysis (Figs. 2-3) exhibited differences in the cluster groupings at the littoral and limnetic regions. The monthly variations in abundance of zooplankton, important groups and species are indicated in Table 2 as well as June 1995-May 1996 survey, and the details are presented in Appendices I-II. Zooplankton abundance ranged between 131-279 and 96-425 ind. $1^{-1}$ and comprised between $23.3 \pm 10.0,32.2 \pm 10.6 \%$ of net plankton abundance at the littoral and limnetic regions respectively (Table 2 ). Rotifera (27-158, $67-315$ ind. $\left.1^{-1}\right)$, Copepoda (30-97, 8-122 ind..$\left.^{-1}\right)$, and Cladocera (29-48, 7-29 ind. ${ }^{-1}$ ) comprised between $37.3 \pm 17.1, \quad 69.7 \pm 14.0 \% ; \quad 40.5 \pm 18.2$, $19.2 \pm 11.7 \%$; and $19.0 \pm 5.3,7.9 \pm 3.8 \%$ of zooplankton abundance at the two regions respectively (Table 2). Rhizopoda and Ostracoda recorded low densities. Brachionidae $(25 \pm 33$, $48 \pm 57$ ind. $\left.^{-1}\right)$ and Cyclopidae $(60 \pm 42,31 \pm 27$ ind. $1^{-1}$ ) are notable families, while Bosminidae $\left.\left(13 \pm 7,9 \pm 5 \text { ind }^{-1}\right)^{-1}\right)$ and Chydoridae $(13 \pm 4,4 \pm 3$ ind. $\left.1^{-1}\right)$ indicated limited importance; the species

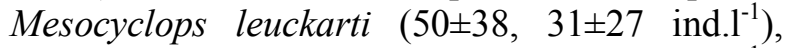
Keratella cochlearis $\left(20 \pm 34,47 \pm 57\right.$ ind. $\left.1^{-1}\right)$, Ascomorpha ovalis $\left(19 \pm 21, \quad 27 \pm 17 \quad\right.$ ind. $\left.1^{-1}\right)$ indicated importance at the two regions, respectively. In addition, Conochilus unicornis (36 \pm 49 ind. $\left.1^{-1}\right)$, Asplanchna priodonta $\left(17 \pm 17\right.$ ind..$\left.^{-1}\right)$ and Polyarthra vulgaris $\left(10 \pm 6\right.$ ind. $\left.1^{-1}\right)$ deserved attention in the limnetic collections, and Microcyclops hyalinus $\left(10 \pm 4\right.$ ind. $\left.^{-1}\right)$ is notable at the littoral region. The significance of various abiotic and biotic factors (vide ANOVA) between the littoral and limnetic regions and months are indicated in Table 3. Zooplankton species diversity (Fig. 4) ranged between 2.047-3.481 and 1.607-2.847 (2.217 \pm 0.327$)$, and evenness and dominance between $0.596-0.881$ and 0.520 -0.838 , and $0.146-0.502$ and $0.185-0.459$, at the two regions, respectively. Rotifera richness is 
Table 1. Variations of abiotic factors

\begin{tabular}{|c|c|c|c|c|c|}
\hline Stations $\longrightarrow$ & \multicolumn{2}{|c|}{ Littoral region } & \multicolumn{2}{|c|}{ Limnetic region } & June 1995-May 96 \\
\hline Factors $\downarrow$ & Range & Mean \pm S.D & Range & Mean \pm S.D & Mean \pm S.D \\
\hline Water temperature ${ }^{0} \mathrm{C}$ & $16.0-24.0$ & $20.7 \pm 2.7$ & $16.5-24.5$ & $20.8 \pm 2.6$ & $21.1 \pm 4.4$ \\
\hline $\begin{array}{ll}\text { Rainfall } & \mathrm{mm} \\
\end{array}$ & $1.4-803.2$ & $230.2 \pm 227.8$ & $1.4 \mathrm{v} 803.2$ & $230.2 \pm 227.8$ & $175.2 \pm 206.8$ \\
\hline Transparency & $75-110$ & $92.5 \pm 10.1$ & $80-120$ & $100.8 \pm 12.4$ & $1.9 \pm 0.4$ \\
\hline $\mathrm{pH}$ & $6.7-7.2$ & $6.95 \pm 0.16$ & $6.8-7.2$ & $6.95 \pm 0.13$ & $8.1 \pm 0.6$ \\
\hline Specific conductivity $\mu \mathrm{S} / \mathrm{cm}^{-1}$ & $40.2-57.8$ & $50.3 \pm 5.3$ & $38.8-58.0$ & $50.0 \pm 6.3$ & $35.5 \pm 7.7$ \\
\hline Dissolved oxygen $\quad \mathrm{mg} \mathrm{l}^{-1}$ & $7.0-9.6$ & $8.2 \pm 0.7$ & $7.4-9.0$ & $8.3 \pm 0.6$ & $6.5 \pm 0.6$ \\
\hline Free Carbon dioxide & $9.0-14.0$ & $11.3 \pm 1.5$ & $6.0-8.0$ & $7.1 \pm 0.9$ & $2.8 \pm 0.9$ \\
\hline Total Alkalinity & $24.0-48.0$ & $33.0 \pm 6.8$ & $28.0-46.8$ & $36.3 \pm 5.7$ & $27.5 \pm 5.7$ \\
\hline Total Hardness & $16.8-32.0$ & $23.0 \pm 4.8$ & $18.6-38.8$ & $25.6 \pm 5.8$ & $21.5 \pm 5.7$ \\
\hline Calcium & $9.8-19.2$ & $13.9 \pm 3.4$ & $10.0-18.7$ & $13.7 \pm 2.6$ & $10.6 \pm 3.3$ \\
\hline Magnesium & $1.2-4.2$ & $2.2 \pm 0.8$ & $1.0-5.0$ & $2.2 \pm 1.1$ & $2.6 \pm 0.9$ \\
\hline Chloride & $12.0-18.0$ & $14.5 \pm 2.1$ & $10.2-17.8$ & $13.7 \pm 2.0$ & $6.7 \pm 1.2$ \\
\hline Phosphate & $0.090-0.208$ & $0.151 \pm 0.041$ & $0.102-0.234$ & $0.160 \pm 0.046$ & $0.13 \pm 0.06$ \\
\hline Sulphate & $0.159-2.020$ & $1.022 \pm 0.664$ & $0.259-2.004$ & $0.939 \pm 0.558$ & $5.5 \pm 2.2$ \\
\hline $\begin{array}{ll}\text { Nitrate } & \mathrm{mg} / \mathrm{l} \\
\end{array}$ & $0.062-0.108$ & $0.090 \pm 0.016$ & $0.052-0.110$ & $0.086 \pm 0.016$ & $1.3 \pm \mathrm{I} . \mathrm{I}$ \\
\hline Dissolved organic matter $\mathrm{mg} \mathrm{l}^{-1}$ & $2.2-4.8$ & $3.1 \pm 0.7$ & $1.6-3.4$ & $2.1 \pm 0.6$ & - \\
\hline
\end{tabular}

Table 2. Qualitative and quantitative variations of zooplankton

\begin{tabular}{|c|c|c|c|}
\hline \multicolumn{4}{|c|}{ RICHNESS } \\
\hline & Littoral region & Limnetic region & June 1995-May 1996 \\
\hline Zooplankton $\quad$ Total & 56 species & 41 species & 28 species \\
\hline $\begin{array}{r}\text { Monthly } \\
\text { Community similarity }\end{array}$ & $\begin{array}{c}27-52 \quad 35 \pm 6 \\
57.6-85.7 \%\end{array}$ & $\begin{array}{c}19-32 \quad 22 \pm 3 \\
51.1-88.9 \%\end{array}$ & $10-22 \quad 15 \pm 3$ \\
\hline \multirow{2}{*}{$\begin{array}{lc}\text { Rotifera } & \begin{array}{c}\text { Total } \\
\text { Monthly }\end{array}\end{array}$} & \multirow{2}{*}{$\begin{array}{c}32 \text { species } \\
13-31 \quad 18 \pm 4\end{array}$} & 23 species & \multirow{2}{*}{14 species } \\
\hline & & $10-17 \quad 12 \pm 2$ & \\
\hline \multicolumn{4}{|c|}{ ABUNDANCE } \\
\hline Net Plankton ind. ${ }^{-1}$ & $1053 \pm 421$ & $363-1346$ & $80-312 \quad 164 \pm 77$ \\
\hline Zooplankton & $200 \pm 42$ & $218 \pm 103$ & $17-109 \quad 55 \pm 26$ \\
\hline Percentage & $10.4-35.2 \quad 23.3 \pm 10.0$ & $30.2 \pm 10.6$ & $43.6 \pm 26.4$ \\
\hline Species Diversity & $2.047-3.481 \quad 2.584 \pm 0.378$ & $1.607-2.847 \quad 2.217 \pm 0.327$ & $1.891-2.840 \quad 2.254 \pm 0.289$ \\
\hline Dominance & $0.146-0.502 \quad 0.329 \pm 0.126$ & $0.185-0.459 \quad 0.351 \pm 0.112$ & $0.133-0.392 \quad 0.296 \pm 0.098$ \\
\hline Evenness & $0.596-0.881 \quad 0.727 \pm 0.086$ & $0.520-0.838 \quad 0.717 \pm 0.096$ & $0.761-0.988 \quad 0.838 \pm 0.090$ \\
\hline \multicolumn{4}{|c|}{ Important Groups } \\
\hline Rotifera & $78 \pm 43$ & $151 \pm 80$ & $5-13$ \\
\hline Percentage & $37.3 \pm 17.1$ & $69.7 \pm 14.0$ & \\
\hline Copepoda & $82 \pm 46$ & $48 \pm 34$ & $31 \pm 26$ \\
\hline Percentage & $40.5 \pm 18.2$ & $19.2 \pm 11.7$ & \\
\hline $\begin{array}{l}\text { Cladocera } \\
\text { Percentage }\end{array}$ & $\begin{array}{c}36 \pm 6 \\
19.0 \pm 5.3\end{array}$ & $\begin{array}{l}7-29 \\
3.0-17.1\end{array}$ & $3-34 \quad 14 \pm 9$ \\
\hline \multicolumn{4}{|c|}{ Important Families (ind. $\mathrm{I}^{-1}$ ) } \\
\hline Brachinoidae & $25 \pm 33$ & $48 \pm 57$ & - \\
\hline Cyclopidae & $60 \pm 42$ & $31 \pm 27$ & - \\
\hline Bosminidae & $13 \pm 7$ & $9 \pm 5$ & - \\
\hline Chydoridae & $13 \pm 4$ & $4 \pm 3$ & - \\
\hline \multicolumn{4}{|c|}{ Important Species $\left(\right.$ ind. $^{-1}$ ) } \\
\hline Mesocyclops leuckarti & $50 \pm 38$ & $31 \pm 27$ & - \\
\hline Keratella cochlearis & $22 \pm 34$ & $47 \pm 57$ & - \\
\hline Ascomorpha ovalis & $19 \pm 21$ & $27 \pm 17$ & - \\
\hline Asplanchna priodonta & $8 \pm 5$ & $17 \pm 17$ & - \\
\hline Conochilus unicornis & $5 \pm 3$ & $36 \pm 49$ & - \\
\hline Polyarthra vulgaris & $5 \pm 5$ & $10 \pm 6$ & - \\
\hline Microcyclops hyalinus & $10 \pm 4$ & $0 \pm 1$ & - \\
\hline
\end{tabular}




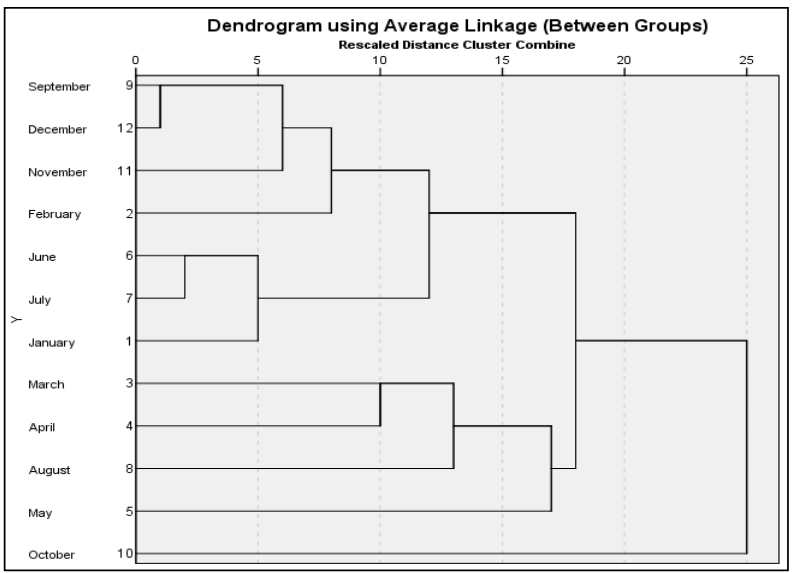

Figure 2. Hierarchical cluster analysis of zooplankton assemblages (Littoral region).

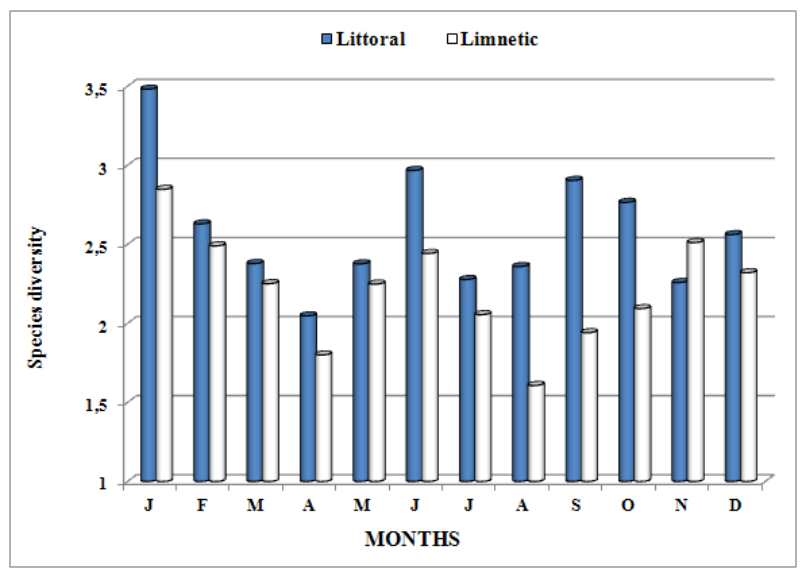

Figure 4. Monthly variations of zooplankton species diversity

inversely influenced by phosphate $\left(\mathrm{r}_{2}=-0.688, \mathrm{p}\right.$ $=0.0279)$ at the limnetic region, and zooplankton $\left(\mathrm{r}_{2}=0.697, \mathrm{p}=0.0251\right)$ and Rotifera $\left(\mathrm{r}_{2}=0.679, \mathrm{p}\right.$ $=0.0308)$ richness is positively correlated with dissolved organic matter at the littoral region. Cladocera abundance is inversely influenced by free carbon dioxide $\left(\mathrm{r}_{1}=-0.730, \mathrm{p}=0.0165\right)$ and nitrate $\left(\mathrm{r}_{1}=-0.691, \mathrm{p}=0.0251\right)$; Rotifera abundance by specific conductivity $\left(\mathrm{r}_{1}=-0.667, \mathrm{p}=\right.$ 0.0351 ) at the littoral region; and the latter is positively correlated with water abundance $\left(r_{2}=\right.$ $0.697, \mathrm{p}=0.0251)$ at the limnetic region. Brachionidae is inversely influenced by transparency $\left(r_{1}\right.$ $=-0.784, p=0.0073)$ and specific conductivity $\left(r_{1}\right.$ $=-0.690, p=0.0272)$ and positively influenced by sulphate $\left(\mathrm{r}_{1}=0.744, \mathrm{p}=0.0136\right)$ at the littoral

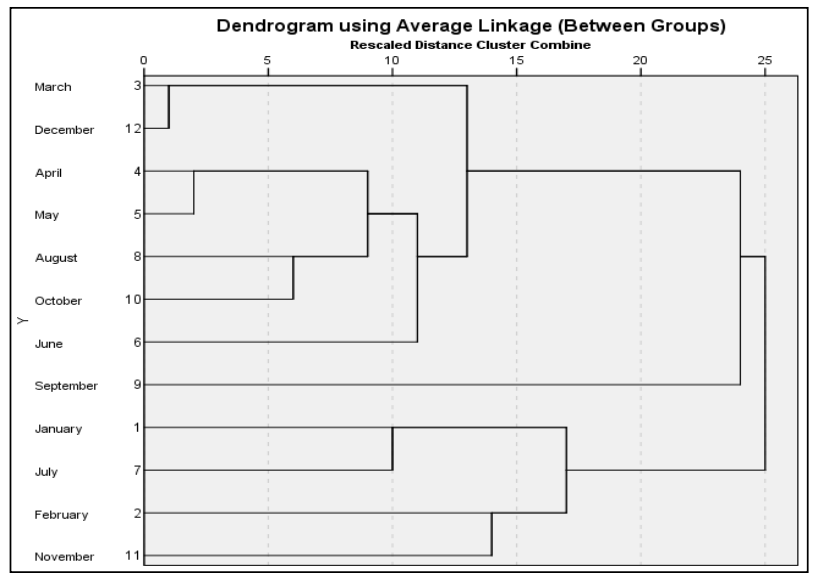

Figure 3. Hierarchical cluster analysis of zooplankton assemblages (Limnetic region)

region; it is positively influenced water temperature $\left(r_{2}=0.681, p=0.0302\right)$ and sulphate $\left(r_{2}=\right.$ $0.772, p=0.0089)$ and inversely influenced by transparency $\left(r_{2}=-0.721, p=0.0186\right)$, total alkalinity $\left(\mathrm{r}_{2}=-0.760, \mathrm{p}=0.0189\right)$ and calcium $\left(\mathrm{r}_{2}\right.$ $=-0.732, \mathrm{p}=0.0161) ;$ and Chydoridae is positively $\left(\mathrm{r}_{2}=0.859, \mathrm{p}=0.0016\right)$ influenced by dissolved organic matter at the limnetic region. Keratella cochlearis recorded inverse correlation with transparency $\left(\mathrm{r}_{1}=-0.759, \mathrm{p}=0.0109\right)$ and specific conductivity $\left(\mathrm{r}_{1}=-0.673, \mathrm{p}=0.033\right)$ and is positively influenced by sulphate $\left(\mathrm{r}_{1}=0.736, \mathrm{p}\right.$ $=0.0152) ;$ Ascomorpha ovalis is positively influenced by total alkalinity $\left(\mathrm{r}_{1}=0.771, \mathrm{p}=\right.$ $0.009)$, total hardness $\left(r_{1}=0.772, p=0.0089\right)$ and dissolved organic matter $\left(r_{1}=0.716, p=0.0199\right)$ and calcium $\left(\mathrm{r}_{1}=0.695, \mathrm{p}=0.0263\right)$; and Asplanchna priodonta is positively influenced by dissolved oxygen $\left(r_{1}=0.838, p=0.0025\right)$, total alkalinity $\left(\mathrm{r}_{1}=0.883, \mathrm{p}=0.0007\right)$, total hardness $\left(\mathrm{r}_{1}=0.932, \mathrm{p}<0.0001\right)$, calcium $\left(\mathrm{r}_{1}=0.914, \mathrm{p}\right.$ $=0.0002)$, and magnesium $\left(\mathrm{r}_{1}=0.767, \mathrm{p}=0.0096\right)$, and inversely by sulphate $\left(\mathrm{r}_{1}=-0.775, \mathrm{p}=0.0085\right)$ at the littoral region. Ascomorpha ovalis is inversely influenced by dissolved oxygen $\left(\mathrm{r}_{2}=\right.$ $0.689, \mathrm{p}=0.027) ;$ Keratella cochlearis is positively influenced by water temperature $\left(r_{2}=\right.$ $0.690, \mathrm{p}=0.027)$ and sulphate $\left(\mathrm{r}_{2}=0.775, \mathrm{p}=\right.$ 0.008 ) and is inversely influenced by transparency $\left(r_{2}=-0.716, p=0.011\right)$, total alkalinity $\left(r_{2}=-0.764\right.$, $\mathrm{p}=0.010)$ and calcium $\left(\mathrm{r}_{2}=-0.738, \mathrm{p}=0.015\right)$; and Asplanchna priodonta is positively influenced 


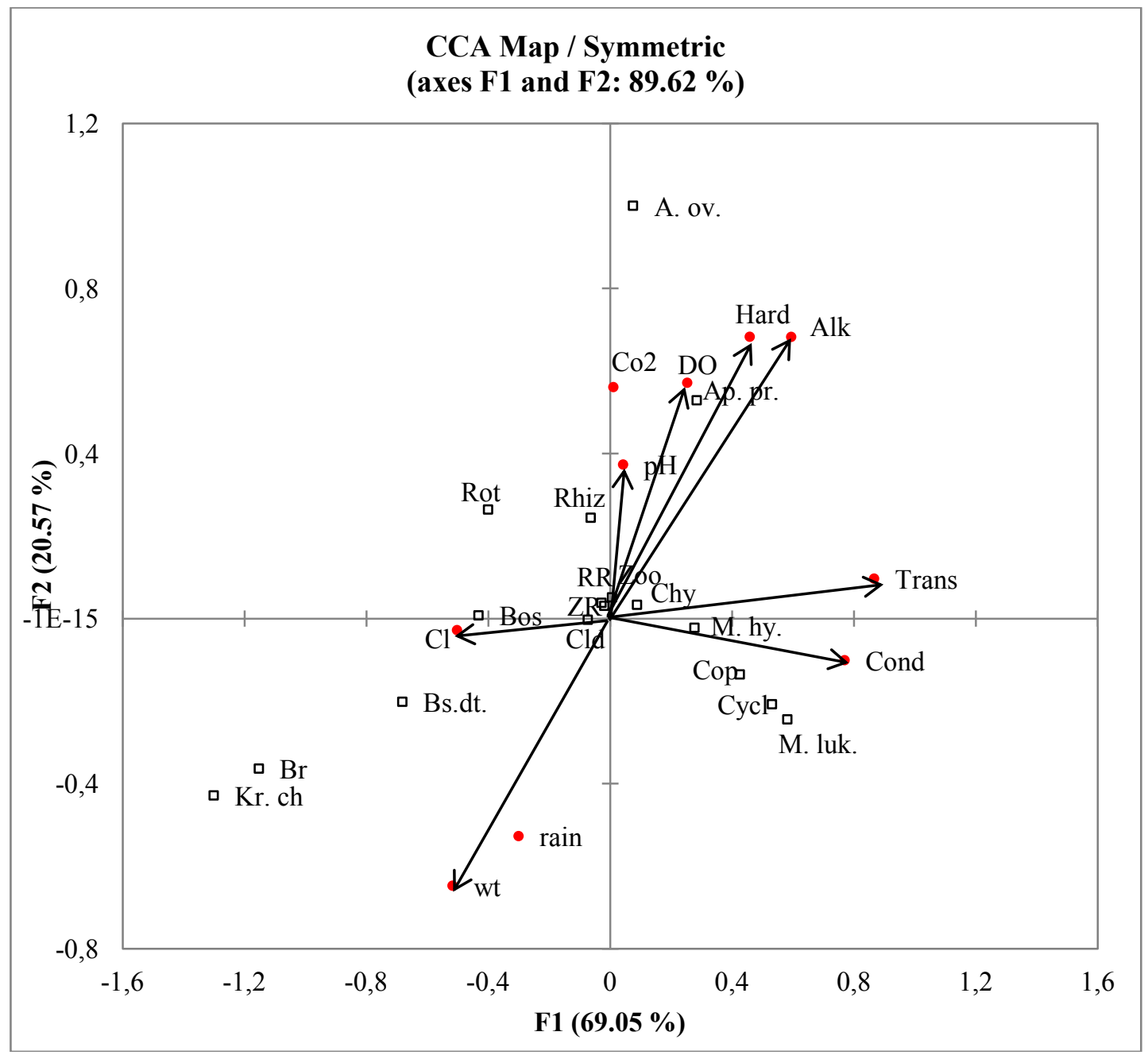

Figure 5. CCA coordination biplot of zooplankton and abiotic factors (Littoral region).

\begin{abstract}
Abbreviations: Abiotic factors: Alk (alkalinity), $\mathrm{Cl}$ (Chloride), Cond (specific conductivity), $\mathrm{Co} 2$ (free carbon dioxide, DO (dissolved oxygen), rain (rainfall), Trans (transparency), Hard (hardness), pH (hydrogen-ion concentration), wt (water temperature). Biotic factors: A. ov. (Ascomorpha ovalis abundance), Ap. pr. (Asplanchna priodonta abundance). Bos (Bosminidae abundance), Br (Brachionidae abundance), Bs. dt. (Bosminopsis deitersi abundance), Chy (Chydoridae abundance), Cld (Cladocera abundance), ClR (Cladocera richness), Cop (Copepoda abundance), Cycl (Cyclopidae abundance), Kr. ch. (Keratella cochlearis abundance) M. hy. (Microcyclops hyalinus abundance), M. luk. (Mesocyclops leuckarti abundance), Rot (Rotifera abundance), RR (Rotifera richness), Rz (Rhizopoda abundance), Zoo (Zooplankton abundance), ZR (Zooplankton richness).
\end{abstract}

by total alkalinity $\left(\mathrm{r}_{2}=0.787, \mathrm{p}=0.007\right)$, total hardness $\left(\mathrm{r}_{2}=0.812, \mathrm{p}=0.0043\right)$ and sulphate $\left(\mathrm{r}_{2}=\right.$ $0.791, \mathrm{p}=0.006)$ at the limnetic region. The Canonical correspondence analysis (CCA) with
10 abiotic factors registered cumulative influence of 89.62 and $74.79 \%$, along axis 1 and 2 , on zooplankton assemblages at the littoral and limnetic regions, respectively (Figs. 5-6). 


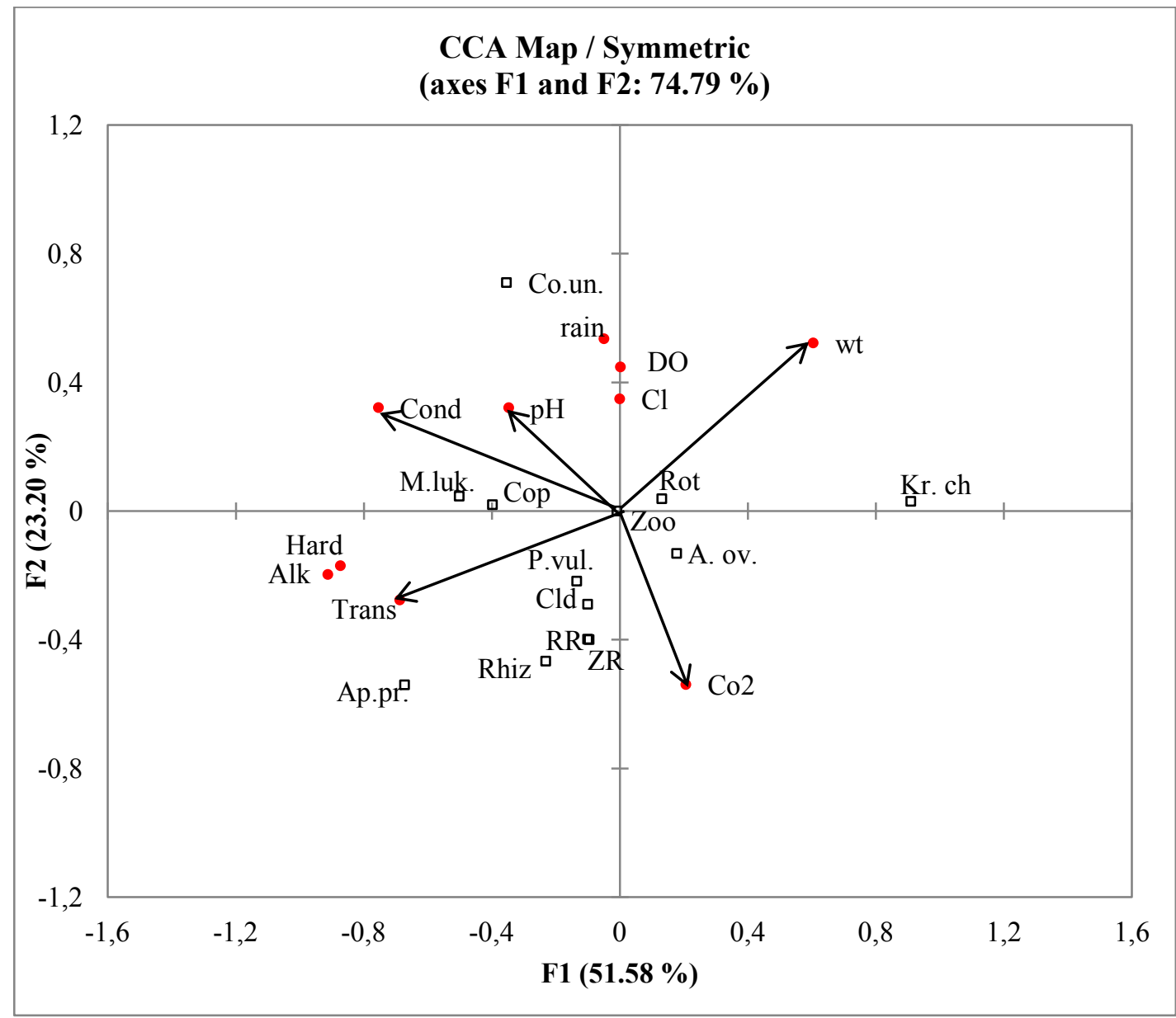

Figure. 6. CCA coordination biplot of zooplankton and abiotic factors (Limnetic region)

\begin{abstract}
Abbreviations: Abiotic factors: Alk (alkalinity), $\mathrm{Cl}$ (Chloride), Cond (specific conductivity), Co2 (free carbon dioxide, DO (dissolved oxygen), rain (rainfall), Trans (transparency), Hard (hardness), pH (hydrogen-ion concentration), wt (water temperature). Biotic factors: A. ov. (Ascomorpha ovalis abundance), Ap. pr. (Asplanchna priodonta abundance). Bos (Bosminidae abundance), Br (Brachionidae abundance), Chy (Chydoridae), Cld (Cladocera abundance), ClR (Cladocera richness), Co.un. (Conochilus unicornis abundance), Cop (Copepoda), Cycl (Cyclopidae abundance), Kr. ch. (Keratella cochlearis abundance) M. hy. (Microcyclops hyalinus), M. luk. (Mesocyclops leuckarti abundance), P. vul (Polyarthra vulgaris), Rot (Rotifera abundance), RR (Rotifera richness), Rz (Rhizopoda abundance), Zoo (Zooplankton abundance), ZR (Zooplankton richness).
\end{abstract}

Table 3: ANOVA indicating significance of abiotic and biotic factors

\begin{tabular}{|c|c|c|}
\hline Parameters & Regions & Months \\
\hline \multicolumn{3}{|c|}{ Abiotic factors } \\
\hline Water temperature & - & $\mathrm{F}_{11,23}=233.294, \mathrm{P}=2.19 \mathrm{E}-11$ \\
\hline Transparency & $\mathrm{F}_{1,23}=17.742, \mathrm{P}=0.001$ & $\mathrm{~F}_{11,23}=10.871, \mathrm{P}=0.0002$ \\
\hline $\mathrm{pH}$ & - & - \\
\hline Specific conductivity & - & $\mathrm{F}_{11,23}=11.1508, \mathrm{P}=0.0002$ \\
\hline Dissolved oxygen & - & - \\
\hline Free Carbon dioxide & $\mathrm{F}_{1,23}=73.565, \mathrm{P}=3.35 \mathrm{E}-06$ & - \\
\hline Total Alkalinity & $\mathrm{F}_{1,23}=23.683, \mathrm{P}=0.0005$ & $\mathrm{~F}_{11,23}=30.097, \mathrm{P}=1.31 \mathrm{E}-06$ \\
\hline
\end{tabular}




\begin{tabular}{|c|c|c|}
\hline Parameters & Regions & Months \\
\hline \multicolumn{3}{|c|}{ Abiotic factors } \\
\hline Total Hardness & $\mathrm{F}_{1,23}=30.644, \mathrm{P}=0.0002$ & $\mathrm{~F}_{11,23}=43.616, \mathrm{P}=1.87 \mathrm{E}-07$ \\
\hline Calcium & - & $F_{11,23}=31.712, P=9.99 \mathrm{E}-07$ \\
\hline Magnesium & - & $\mathrm{F}_{11,23}=26.706, \mathrm{P}=2.44 \mathrm{E}-06$ \\
\hline Chloride & - & $\mathrm{F}_{11.23}=6.0970, \mathrm{P}=0.0028$ \\
\hline Phosphate & - & $\mathrm{F}_{11,23}=8.972, \mathrm{P}=0.0005$ \\
\hline Sulphate & - & $\mathrm{F}_{11,23}=30.302, \mathrm{P}=1.27 \mathrm{E}-06$ \\
\hline Nitrate & - & $\mathrm{F}_{11.23}=15.625, \mathrm{P}=3.68 \mathrm{E}-05$ \\
\hline Dissolved organic matter & $\mathrm{F}_{1.23}=31.132, \mathrm{P}=0.0002$ & $\mathrm{~F}_{11.23-}=3.893, \mathrm{P}=0.016$ \\
\hline \multicolumn{3}{|l|}{ Biotic factors } \\
\hline \multicolumn{3}{|c|}{ Richness } \\
\hline Zooplankton & $\mathrm{F}_{1.23}=129.717, \mathrm{P}=1.99 \mathrm{E}-07$ & $\mathrm{~F}_{11,23}=5.545, \mathrm{P}=0.0042$ \\
\hline Rotifera & $\mathrm{F}_{1,23}=23.862, \mathrm{P}=0.0004$ & - \\
\hline \multicolumn{3}{|c|}{ Abundance } \\
\hline Zooplankton & - & - \\
\hline Rotifera & $\mathrm{F}_{1,23}=9.323, \mathrm{P}=0.011$ & - \\
\hline Copepoda & $\mathrm{F}_{1,23}=168.163, \mathrm{P}=5.22 \mathrm{E}-08$ & $\mathrm{~F}_{11,23}=3.098, \mathrm{P}=0.036$ \\
\hline Cladocera & $\mathrm{F}_{1,23}=168.163, \mathrm{P}=5.22 \mathrm{E}-08$ & $\mathrm{~F}_{11,23}=3.820, \mathrm{P}=0.018$ \\
\hline Zooplankton species diversity & $\mathrm{F}_{1,23}=13.684, \mathrm{P}=0.003$ & $\mathrm{~F}_{11,23}=3.631, \mathrm{P}=0.021$ \\
\hline \multicolumn{3}{|c|}{ Important families } \\
\hline Cyclopidae & $\mathrm{F}_{1,23}=8.987, \mathrm{P}=0.012$ & $\mathrm{~F}_{11,23}=3.850, \mathrm{P}=0.017$ \\
\hline Brachinoidae & $\mathrm{F}_{1,23}=5.478, \mathrm{P}=0.039$ & - \\
\hline Bosminidae & $\mathrm{F}_{1,23}=5.110, \mathrm{P}=0.045$ & - \\
\hline Chydoridae & $\mathrm{F}_{1,23}=54.397, \mathrm{P}=1.4 \mathrm{E}-05$ & - \\
\hline \multicolumn{3}{|c|}{ Important species } \\
\hline Mesocyclops leuckarti & $\mathrm{F}_{1,23}=4.314, \mathrm{P}=0.013$ & - \\
\hline Keratella cochlearis & $\mathrm{F}_{1.23}=6.157, \mathrm{P}=0.030$ & $\mathrm{~F}_{11,23}=6.973, \mathrm{P}=0.002$ \\
\hline Ascomorpha ovalis & - & - \\
\hline Asplanchna priodonta & $\mathrm{F}_{1,23}=8.564, \mathrm{P}=0.012$ & $\mathrm{~F}_{11,23}=3.105, \mathrm{P}=0.025$ \\
\hline
\end{tabular}

(-) indicates insignificant variations

\section{DISCUSSION}

The sub-tropical Nongmahir reservoir is characterized by soft, slightly acidic - circum neutral and calcium poor waters with low specific conductivity, chloride and nutrients. Low specific conductivity is attributed to leached and weathered nature of rocks and soils because of high rainfall in NEI (Sharma 1995) and the lowered buffering capacity of the de-mineralized waters (Steinitz-Kannan et al. 1983). ANOVA indicated significant variations of free carbon dioxide between stations; transparency, total alkalinity, total hardness and dissolved organic matter indicated significant variations between regions and months, while water temperature, specific conductivity, calcium, magnesium, chloride, phosphate, nitrate and sulphate recorded significant monthly variations. In all 12 abiotic factors registered significant monthly variations and only 5 factors registered significant variations between the regions; the differences are hypothesized to habitat diversity of the sampled regions. This study depicted decreased transparency, magnesium, sulphate and nitrate, and relative increase in specific conductivity, free carbon dioxide, total alkalinity, total hardness, calcium, phosphate and nitrate than earlier preliminary report (Sharma \& Lyngskor 2003).

Fifty-six species belonging to 37 genera and 22 families observed vide our study revealed one of the biodiverse zooplankton assemblage known from the tropical and subtropical lacustrine environs of India; this salient feature is attributed to overall environmental heterogeneity of Nongmahir reservoir. Our remarks are affirmed by higher richness known than the reports from lakes and reservoirs of Andhra Pradesh (Sharmila \& Shameem 2017), Karnataka (Hulyal \& Kaliwal 
2008, Kudari \& Kanamadi 2008, Rajashekhar et al. 2008, Majagi \& Vijaykumar 2009, Shivashankar \& Venkataramana 2013, Ramalingappa et al. 2015, Anita et al. 2019, Basawarajeshwari 2019, Majagi et al. 2019), Kashmir (Khan 1987, Raina \& Vass 1993, Ahangar et al. 2012, Jeelani \& Kaur 2014), Madhya Pradesh (Khandayat \& Singh 2019), Meghalaya (Sharma 1995, Das et al. 1996, Sharma \& Lyngdoh 2004), Mizoram (Sharma \& Pachuau 2013), Rajasthan (Shwetanshumala \& Sharma 2020), Tamil Nadu (Manickam et al. 2017, 2018) and Uttarakhand (Negi \& Pant 1983, Mishra et al. 2010, Malik \& Panwar 2016, Sharma \& Kumari 2018, Singh \& Sharma 2020), and water bodies of Nepal (Tiwari \& Chhetry 2009), Bangladesh (Islam \& Chowdhury 2013), Bhutan (Sharma and Bhattarai 2005) and Myanmar (Twin \& Aung 2019). This study also registered a distinct two-fold richness increase than our earlier report (Sharma \& Lyngskor 2003). The reports of 56 and 41 species, with $84.5 \%$ community similarity, depicted zooplankton homogeneity amongst from the two regions. Rotifera, the most speciose group, highlighted paucity of the Brachionidae and Brachionus spp. in slightly acidic - circum neutral waters concurrent with the reports of Sharma (1995), Sharma \& Pachuau (2013) and Sharma et al. (2016). Peak rotifer (31 species) richness noted during January from the littoral region depicted speciose constellation. The rotifers recorded higher richness than known from lacustrine environs of Meghalaya (Sharma 1995, Sharma \& Lyngdoh 2004), Mizoram (Sharma \& Pachuau 2013), Kashmir (Raina \& Vass 1993, Wani \& Subla 1995, Jeelani \& Kaur 2014, Shah et al. 2017, Jamila, 2018), Uttarakhand (Inaotombi et al. 2016), Bangladesh (Islam \& Chowdhury 2013) and Myanmar (Twin \& Aung 2019).

Zooplankton richness followed oscillating monthly spatial variations; higher richness at the littoral $>$ the limnetic region is hypothesized to greater habitat diversity of the former region. Peak consortium / sample of 52 species at the littoral region during January (winter) collection supported habitat diversity assertion; such assemblage is attributed to the possibility of co- existence of speciose constellation as hypothesized by MacArthur (1965). Zooplankton registered $57.6-85.7 \%$ and $51.1-88.9 \%$ community similarities with peak values between SeptemberDecember and March-December and thus depicted heterogeneity at the two regions, respectively. This generalization is supported by $61-$ $70 \%$ and $71-80 \%$ similarities in $\sim 36 \%$ and $\sim 55 \%$ instances at the littoral region, while the limnetic region recorded $51-60 \%, 61-70 \%$ and $71-80 \%$ similarities in $\sim 20 \%, \sim 42 \%$ and $\sim 34 \%$. The hierarchical cluster analysis indicated closer affinities between September-December $>$ JuneJuly assemblages while October collection indicated peak divergence at the littoral region. The limnetic region showed high affinity between March-December > April-May and maximum divergence during September collections. Overall variations in cluster groupings endorsed spatial heterogeneity amongst the two regions. Rotifera influenced zooplankton richness at the littoral $\left(\mathrm{r}_{1}\right.$ $=0.975, \mathrm{p}<.0001)$ and limnetic $\left(\mathrm{r}_{2}=0.918, \mathrm{p}=\right.$ 0.0002 ) regions.

Zooplankton indicated low abundance with wider variations at the limnetic than the littoral region. Low abundance is attributed to 'soft' waters with 'low ionic concentrations' of Nongmahir reservoir; our results thus concurred with the reports, from waters with identical features, from Meghalaya (Sharma 1995), Manipur (Sharma 2011a), Assam (Sharma \& Sharma 2012, Sharma \& Noroh 2020), and Mizoram (Sharma \& Pachuau 2013) states of NEI, and from Bhutan (Sharma \& Bhattarai 2005). Zooplankton comprised subdominant component of net plankton at the two regions; this generalization concurred with the reports from Assam (Sharma \& Hatimuria 2017), Himachal Pradesh (Jindal \& Prajapat 2005, Jindal \& Thakur 2014), Meghalaya (Sharma 1995, Sharma \& Lyngdoh 2003) and Mizoram (Sharma \& Pachuau 2013). We recorded a distinct increase in zooplankton abundance than known from the sampled reservoir (Sharma and Lyngskor, (2003) and it is broadly concurrent with the reservoir of Mizoram (Sharma \& Pachuau 2013). This study showed oscillating and differential spatial density variations; the latter is 
affirmed by higher abundance at the limnetic $>$ littoral region from April-September, while the littoral > limnetic pattern was noted from January-Match and October-December. Peak April abundance, at both the regions, and maxima during August concurred with the report from Uttarakhand (Negi \& Pant 1983) and monsoon maxima agreed with the report from Myanmar (Twin \& Aung 2019). Besides, peak agreed with summer peaks from Andhra Pradesh (Sharmila \& Shameem 2017), Karnataka (Hulyal \& Kaliwal 2008, Majagi \& Vijaykumar 2009, Shivashankar \& Venkataramana 2013, Anita et al. 2019; Majagi et al. 2019, Basawarajeshwari 2019), Tamil Nadu (Manickam et al. 2017, 2018) but differed from winter peeks known from Madhya Pradesh (Khandayat \& Singh 2019) and Uttarakhand (Sharma \& Pant 1984, Malik \& Panwar 2016, Singh \& Sharma 2020). We observed differential spatial importance of Copepoda $>$ Rotifera at the littoral region but with no overall significant influence on zooplankton. On the contrary, Rotifera $\left(\mathrm{r}_{2}=0.942, \mathrm{p}<0.0001\right)>$ Copepoda $\left(\mathrm{r}_{2}=\right.$ $0.726, \mathrm{p}=0.0174)$ contributed to zooplankton abundance at the limnetic region with the former indicating importance $v s$. August maxima, while Rotifera $>$ Copepoda contributed to peak during April.

Zooplankton depicted spatial differences in quantitative importance of Mesocyclops leuckarti $>$ Keratella cochlearis > Ascomorpha ovalis > Microcyclops hyalinus at the littoral, and of Keratella cochlearis $>$ Conochilus unicornis $>$ Mesocyclops leuckarti > Ascomorpha ovalis $>$ Asplanchna priodonta $>$ Polyarthra vulgaris at the limnetic region. We categorize these as 'specialist' species in contrast to the rest of 'generalist' species with lower densities. Following MacArthur's (1965) explanation, it is thus hypothesized that Nongmahir reservoir has resources for utilization by fewer 'specialist' and majority of 'generalist' species. Mesocyclops leuckarti contributed to zooplankton peak in April with Microcyclops hyalinus > Ascomorpha ovalis > Asplanchna priodonta $>$ Chydorus sphaericus and Keratella cochlearis contributed to August maxima with Ascomorpha ovalis $>$ Polyarthra vulgaris $>$ Bosminopsis deitersi $>$ Conochilus unicornis $>$ Mesocyclops leuckarti at the littoral region. Besides, Conochilus unicornis $>$ Mesocyclops leuckarti influenced April peak at the limnetic region with Ascomorpha ovalis $>A s-$ planchna priodonta $>K$. cochlearis, while $K$. cochlearis influenced August maxima with Asplanchna ovalis $>B$. deitersi $>M$. leuckarti.

The occurrence of 'specialist' species agreed with the report from Mizoram (Sharma \& Pachuau (2013) but differed from 'generalist' nature of species known from reservoirs of Meghalaya (Sharma 1995, Sharma \& Lyngskor 2003), the floodplain lakes of NEI (Sharma, 2011b, 2011b, Sharma \& Sharma 2011, 2020, Sharma \& Noroh 2020), and lakes of Himachal Pradesh (Jindal \& Prajapat 2005; Jindal \& Thakur 2014) and Uttarakhand (Malik \& Panwar 2016; Singh \& Sharma (2020).

Copepoda recorded spatial monthly density variations at the littoral > limnetic regions; ANOVA registered significant variations between regions and months. The quantitative dominance of copepods at the littoral region concurred with the results of Negi \& Pant (1983), Das et al. (1996), Sharma \& Hussain (2001), Sharma \& Pachuau (2013), Malik \& Panwar (2016) and Sharma \& Pant (1984) at Bhimtal Lake of Uttarakhand. The relatively lower abundance at the limnetic region however, agreed with the reports of Sharma (1995, 2011a), Sharma \& Sharma (2012), Ramalingappa et al. (2015), Sharma \& Noroh (2020) and Singh \& Sharma (2020).

This group recorded distinctly higher abundance than the earlier report from Nongmahir reservoir (Sharma \& Lyngskor 2003). Copepoda recorded pre-monsoon peaks at the littoral and limnetic regions and autumn maxima at the littoral region; the former concurred with the reports of Ramalingappa et al. (2015) and Sharmila \& Shameem (2017). Cyclopidae contributed to copepod abundance $\left(\mathrm{r}_{1}=0.994, \mathrm{p}<\right.$ $\left.0.0001 ; r_{2}=0.971, p<0.0001\right)$ at the two regions; recorded significant density variations between 
regions and months (vide ANOVA). This family followed monthly density variations identical to Copepoda with peaks during pre-monsoon at the littoral and limnetic regions and autumn maxima at the littoral region. Mesocyclops leuckarti influenced Copepoda abundance $\left(\mathrm{r}_{1}=0.989, \mathrm{p}<0.0001\right.$; $\left.\mathrm{r}_{2}=0.973, \mathrm{p}<0.0001\right)$ at the two regions, while Microcyclops hyalinus influenced at the littoral region $\left(\mathrm{r}_{2}=0.853, \mathrm{p}=0.0017\right)$. Cyclopidae significance is attributed to the prevalence of stable environmental conditions for these ' $\mathrm{k}$-strategists' as suggested by Allen (1976). The occurrence of nauplii, throughout the study, indicated periods of active reproduction concurrent with the reports of Sharma \& Lyngdoh (2004), Sharma \& Pachuau (2013) and Sharma \& Noroh (2020).

Rotifera recorded significant spatial density variations between the two regions (vide ANOVA); this is affirmed by quantitative dominance of Rotifera $v s$. zooplankton $\left(\mathrm{r}_{2}=0.942\right.$, $\mathrm{p}<0.0001)$ at the limnetic region, while this phylum comprised an important component at the littoral region. Our study indicated higher rotifer abundance than known from the sub-tropical environs of NEI (Sharma 1995, Das et al. 1996, Sharma \& Lyngdoh 2004), while overall Rotifera importance also concurred with reports from subtropical lakes of Kashmir (Jyoti \& Sehgal 1979, Khan 1987, Wani \& Subla 1995, Jamila 2018), Uttarakhand (Negi \& Pant 1983; Sharma \& Pant 1984), Tamil Nadu (Manickam et al. 2017) and the floodplain lakes of NEI (Sharma 2011a, 2011b, Sharma \& Sharma 2008, 2011, 2012, Sharma \& Noroh 2020).

Our results, however, marked a distinct contrast to poor abundance recorded earlier from the sampled reservoir (Sharma \& Lyngskor 2003). Rotifera affirmed differential spatial variations $v s$. maxima during spring and peak in monsoon (August) at the littoral, and the limnetic region recorded maxima in pre-monsoon (April) and peak in monsoon (August). Both pre-monsoon maxima and monsoon peaks agreed with the report of Ramalingappa et al. (2015), while premonsoon maxima corresponded with summer peaks reported by Paulose \& Meheshwari (2007),
Manickam et al. (2017), Shah et al. (2017), Sharmila \& Shameem (2017), Jamila (2018) and Singh \& Sharma (2020). Brachionidae registered significant spatial density variations between regions (vide ANOVA); it showed importance from July-August (peak in July) and from JulyOctober (peak in August) at the two regions, respectively but contributed to Rotifera abundance $\left(\mathrm{r}_{1}=0.681, \mathrm{p}=0.0302\right)$ at the littoral region. Keratella cochlearis recorded density variations between regions and months (vide ANOVA) with peaks during July and August at the two regions, respectively but contributed to Brachionidae $\left(\mathrm{r}_{1}=\right.$ $0.999, \mathrm{p}<0.0001)$ at the limnetic region.

Cladocera, sub-dominant group, indicated significant density variations between regions and months (vide ANOVA). It indicated higher abundance at the former region than the reports from Meghalaya (Sharma 1995, Das et al. 1996, Sharma \& Lyngdoh 2004), Mizoram (Sharma \& Pachuau 2013) and Uttarakhand (Negi \& Pant 1983). The cladocerans followed oscillating monthly variations at both regions; recorded peak during June and maxima during winter at the littoral region and peak during June at the limnetic region. The peaks concurred with the reports of Ramalingappa et al. (2015), Sharmila \& Shameem (2017), Sharma \& Noroh (2020), Malik \& Panwar (2016) and Singh \& Sharma (2020) and while winter maxima agreed with the reports from two floodplain lakes of Manipur (Sharma 2011a). Bosminidae and Chydoridae indicated significant spatial variations between the regions (vide ANOVA). Bosminopsis deitersi contributed to abundance and peak of Cladocera $\left(\mathrm{r}_{1}=0.668, \mathrm{p}=\right.$ $0.0348)$ and Bosminidae $\left(\mathrm{r}_{1}=0.942, \mathrm{p}<0.0001\right)$ at the littoral region, while Bosminidae $\left(\mathrm{r}_{2}=0.818, \mathrm{p}\right.$ $=0.0038$ ) influenced Cladocera abundance at the limnetic region. The other zooplankton groups, Rhizopoda and Ostracoda recorded very poor abundance in this study.

Zooplankton registered significant species diversity $(\mathrm{H})$ variations between regions and months (vide ANOVA). Higher diversity at the littoral region > limnetic region, except in November (autumn), is hypothesized to greater 
habitat heterogeneity at the former region. Peak diversity during winter (January) corresponded with peak zooplankton richness; and $\mathrm{H}^{\prime}$ values $>$ 2.9 and $>2.5$ were noted during June (premonsoon) and September (monsoon), and during November (autumn) at the two regions, respectively. The diversity followed oscillating patterns of monthly variations at the two regions. It is influenced by richness and equitability of species concurrent with the remarks of Sager and Hasler (1969) at the littoral region as affirmed by positive influence by richness of zooplankton $\left(\mathrm{r}_{1}=\right.$ $0.759, \mathrm{p}=0.0109)$ and Rotifera $\left(\mathrm{r}_{1}=0.753, \mathrm{p}=\right.$ $0.0119)$, and evenness $\left(r_{1}=0.956, p<0.0001\right)$. On the other hand, the diversity is positively influenced by evenness $\left(r_{2}=0.949, p<0.0001\right)$ but inversely by zooplankton $\left(\mathrm{r}_{2}=-0.669, \mathrm{p}=0.0349\right)$, Rotifera $\left(\mathrm{r}_{2}=-0.861, \mathrm{p}=0.0014\right)$ and Brachionidae $\left(\mathrm{r}_{2}=-0.704, \mathrm{p}=0.0231\right)$ abundance at limnetic region.

The concurrence of high diversity with relatively lower densities of majority of species, at both sampling regions, as supported by positive correlations with evenness, is attributed to ability of co-existence of various species in combination with high micro- and macro-scale habitat heterogeneity as hypothesized by Segers (2008). We recorded wide variations in zooplankton dominance with peak values during April and August at the littoral and limnetic regions, respectively; high values during March, July and November at the former region; and during April, September and October at the limnetic region. These periods corresponded with zooplankton assemblages dominated by 'specialist' species (Whittaker 1965), while lower dominance during rest of the months is shared by a large number of 'generalist' species (Osborne et al. 1976). Further, dominance $\left(\mathrm{r}_{1}=\right.$ $0.893, \mathrm{p}=0.0006 ; \mathrm{r}_{2}=-0.781, \mathrm{p}=0.0076$ ) recorded inverse correlation with zooplankton diversity at both the regions. Equitable occurrence and low densities of 'generalist' species resulted in high evenness concurrent with periods of high species diversity, while occurrence of 'specialist' species culminated in high evenness in selective months. These generalizations are supported by positive correlation of evenness vs. diversity $\left(\mathrm{r}_{1}=\right.$ $\left.0.956 \mathrm{p}<0.0001 ; \mathrm{r}_{2}=0.949 \mathrm{p}<0.0001\right)$ and inverse correlation with dominance $\left(\mathrm{r}_{1}=-0.961 \mathrm{p}\right.$ $\left.<0.0001 ; \mathrm{r}_{2}=-0.889, \mathrm{p}=0.0006\right)$ at both the sampling regions, respectively.

Our study registered limited and differential spatial influence of individual abiotic parameters on richness and abundance of zooplankton and constituent groups at the two regions. These remarks are endorsed by positive correlation of dissolved organic matter on zooplankton and Rotifera richness at the littoral region, while the latter is inversely influenced by phosphate at the limnetic region. Further, Rotifera abundance is positively correlated with water temperature at the limnetic region, and Cladocera abundance is inversely influenced by free carbon dioxide and nitrate, and is inversely influenced by specific conductivity at the littoral region. The limited influence on richness concurred with the results of Sharma \& Sharma (2012), while that on abundance on zooplankton and constituent groups corresponded with the reports of Sharma (2011a), Sharma \& Sharma (2011a, 2020) and Sharma \& Noroh (2020).

The differential spatial significance also holds valid for notable families and 'specialist' species. Brachionidae is inversely influenced by transparency and specific conductivity and positively influenced by sulphate at the littoral region; it is positively influenced water temperature and sulphate and inversely influenced by transparency, total alkalinity and calcium at the limnetic region; Bosminidae is positively correlated with transparency and chloride; and Chydoridae is positively influenced by dissolved organic matter at the limnetic region. Keratella cochlearis recorded inverse correlation with transparency and specific conductivity and is positively influenced by sulphate; Ascomorpha ovalis is positively influenced by total alkalinity, total hardness alkalinity and dissolved organic matter; and Asplanchna priodonta is positively influenced by dissolved oxygen, total alkalinity, total hardness, calcium, and inversely by sulphate at the littoral region. $A$. ovalis is inversely influenced by dissolved oxygen; $K$. cochlearis is positively influenced by 
water temperature and sulphate and inversely influenced by transparency, total alkalinity and calcium; and A. priodonta is positively influenced by total alkalinity, total hardness and sulphate at the limnetic region. In general, the positive correlations of Rotifera, Brachionidae and $K$. cochlearis with water temperature at the limnetic region concurred with the periods of high abundance of these taxa.

The canonical correspondence analysis (CCA) with 10 abiotic factors registered high cumulative influence on the littoral $(89.62 \%)$ and limnetic (74.79\%) zooplankton, constituent groups, and notable families and species along the first two axes. CCA coordination biplot at the littoral region indicated $\sim 69 \%$ and $\sim 20 \%$ influence of abiotic factors along axis 1 and 2, respectively. Water temperature and chloride influenced richness of zooplankton and Cladocera abundance; total alkaninity, total hardness influenced abundance of zooplankton and Asplanchna priodonota; specific conductivity influenced abundance of Microcyclops hyalinus; total alkalinity and transparency influenced Chydoridae abundance at the littoral region. CCA coordination biplot at the limnetic region indicated $\sim 51 \%$ and $\sim 23 \%$ influence of abiotic factors along axis 1 and 2, respectively. Water temperature influenced Rotifera density; specific conductivity and $\mathrm{pH}$ influenced abundance of Copepoda and Mesocyclops leuckarti; and transparency influenced zooplankton abundance at the limnetic region. Our study thus highlighted importance of cumulative influence over individual influence of abiotic factors, while the impact of fish predation in this reservoir yet needs to be assessed. High cumulative influence concurred with $84.8 \%$ cumulative variance reported from a reservoir of Mizoram (Sharma \& Pachuau 2013) but differed from lower cumulative influence observed from certain floodplain lakes of NEI (Sharma 2011a, Sharma \& Sharma 2012, Sharma \& Hatimuria 2017, Sharma \& Noroh 2020).

Our results caution on application of $\mathrm{Q}_{\mathrm{B} / \mathrm{T}}$ trophic status quotient (Sladecek 1983) in view is distinct paucity of Brachionus spp. in soft and slightly acidic - circum neutral waters of Nongmahir reservoir. We, however, consider Shannon Weiner diversity index as a suitable option for assessing the health of aquatic biotopes with values between 1-3 as indicator of moderately polluted condition and less than 1.0 indicating heavy polluted condition (Wilhm and Dorris 1968, Masson 1998, Datta, 2001). The mean diversity values recorded vide this study depicted moderately polluted ('meso-trophic') nature, while monthly variations at the limnetic region particularly during April, August and September reflected 'meso-eutrophic' nature of Nongmahir reservoir.

To sum up, our report on one of the speciose zooplankton assemblage from the (sub) tropical lacustrine environs of India and peak consortium of 52 species/sample depicted regional biodiversity interest and overall environmental heterogeneity of Nongmahir reservoir located in the Indo-Myanmar hot-spot. Low abundance of zooplankton attributed to 'soft' and demineralized waters; the differential spatial patterns of composition, richness, abundance of zooplankton, constituent groups and important taxa, and moderate species diversity with variations of dominance and equitability indicating habitat heterogeneity of the two regions; and resource utilization by both by 'specialist' and 'generalist' species are noteworthy features. Importance of high overall cumulative influence over individual influence of abiotic factors at the two sampled regions is noteworthy, while the impact of fish predation in this reservoir is required to be assessed. The variations recorded in different aspects of zooplankton $v s$. the preliminary survey of June 1995-May 1996 asserted notable temporal variations. In general, this study is an important contribution to zooplankton diversity of lacustrine environs of India and the subtropical reservoirs of NEI in particular.

Acknowledgements - The senior author thanks the Head, Department of Zoology, North-Eastern Hill University, Shillong for laboratory facilities. We thank our reviewers for valuable comments and constructive suggestions. The authors declare no conflict of interest. 


\section{REFERENCES}

AHANGAR, I.A., SAKSENA, D.N. \& MiR, F.M. (2012): Seasonal variation in zooplankton community of Anchar Lake, Kashmir. Universal Journal of Environmental Research and Technology, 2(4): 305-310.

ALLEN, J.D. (1976): Life history patterns in zooplankton. American Naturalist, 110: 165-180. doi: $\underline{10.1086 / 283056}$

Anita, S.M., Hatti, S.S., Majagi, S. \& Chitra, J. (2019): Assessment of Zooplankton Diversity of Nagaral Dam, Chincholli, Kalaburagi. Research Journal of Life Sciences, Bioinformatics, Pharmaceutical and Chemical Sciences, 5(26): 269-281.

A.P.H.A. (1992): Standard Methods for the Examination of Water and Wastewater (18 ${ }^{\text {th }}$ Ed.). American Public Health Association, Washington D.C. 1198 pp.

BASAWARAJESHWARI, I. (2019): Zooplankton diversity in freshwater reservoir of Yadigir District, Karnataka State. International Journal of Research in Advent Technology, 7(2): 621-624.

BhATTACHARYA, T. \& SAHA, R.K. (1986): A comparative study of the physico-chemical conditions of water and plankton of Gumti reservoir, open channel and river below hydal project in Tripura. Proceedings of National Symposium of Fish \& Environment, p. 61-65.

BHATTACHARYA, T. \& SAHA, R.K. (1990): Limnological studies of the Gumti watershed in Tripura. In. MANNA, G.K. \& JANA, B.B. (Eds.) Impacts of Environment on Animals and Aquaculture. Kalyani, India, p. 183-186.

DAS, P.K, Michael R.G. \& GUPTA, A. (1996): Zooplankton community structure in Lake Tasek, a tectonic lake in Garo Hills, India. Tropical Ecology, 37: 257-263.

DATTA, N.C. (2001): Biomonitoring of aquatic environment - concept, scope and limitations. In. SHARMA, B.K. (Ed.) Water quality assessment, Biomonitoring and Zooplankton diversity. Department of Zoology, NEHU, Shillong, p. 36-44.

Hulyal, S.B. \& Kaliwal, B.B. (2008): Kaliwal Water quality assessment of Almatti reservoir of Bijapur (Karnataka state, India) with special reference to zooplankton. Environmental Monitoring and Assessment, 139: 299-306. doi: $10.1007 / \mathrm{s} 10661-007-9835-7$
InAOTOMBI, S., GuPTA, P.K. \& MAHANTA, P.C. (2016): Influence of abiotic factors on the spatio-temporal distribution of Rotifers in a subtropical lake of Western Himalaya. Water Air Soil Pollution, 227: 50. doi: 10.1007/s11270-015-2729-3

ISLAM, M.A. \& CHOWDHURY, A.H (2013): Limnological status of Trimohini Beel of Rajshahi, Bangladesh. Journal of the Asiatic Society of Bangladesh, Science, 39(2): 173-182.

JAMILA, I. (2018): Temporal and spatial variations in Rotifer density with environmental factors of three Kashmir Lakes, India. International Journal of Theoretical \& Applied Sciences, 10(1): 109-116.

JANA, B.B. (1998): State-of-the-art of lakes in India: an overview. Archiv für hydrobiologie, Supplement, 121(1): 1-89.

JeElani, M. \& KauR, H. (2014): Comparative Studies on Zooplankton in Dal Lake, Kashmir, India. Journal of Academic and Industrial Research, 2(9): 534-537.

JindAL, R. \& PRAJAPAT, P. (2005): Productivity and trophic status of Renuka wetland (Distt. Sirmour, Himachal Pradesh. Indian Journal of Ecology, 32(2): 180-183.

JINDAL, R. \& THAKUR, R.K. (2014): Hydrobiology and productivity of Kuntbhyog Lake, (District Mandi, Himachal Pradesh), India. International Journal of Environmental Engineering, 6(4): 449-459.

JiNDAL, R., THAKUR, R.K., Singh, U.B. \& AHLUWALIA, A.S. (2013): Plankton diversity and water quality assessment of three freshwater lakes of Mandi (Himachal Pradesh, India) with special reference to planktonic indicators. Environmental Monitoring \& Assessment, 185(10): 8355-8373. doi: $10.1007 / \mathrm{s} 10661-013-3178-3$

Jyoti, M.K. \& SeHGAL, H. (1979): Ecology of rotifers of Surinsar, a subtropical freshwater lake in Jammu ( J \& K ) India. Hydrobiologia, 65: 23-32. doi: $10.1007 / \mathrm{BF} 00032715$

KHAN, M.A. (1987): Observations on zooplankton composition, abundance and periodicity in two flood-plain lakes of the Kashmir Himalayan valley. Acta Hydrochemica Hydrobiologica, 15: 167-174. doi: $10.1002 /$ aheh.19870150211

Khandayat, P. \& Singh, B.S. (2019): Diversity of zooplankton of Gangulpara dam district Balaghat (M.P.). International Journal of Zoology Studies, 4(2): 60-62. 
KUDARI, V.A. \& KANAMADI, R.D. (2008): Impact of changed trophic status on the zooplankton composition in six water bodies of Dharwad district, Karnataka state (South India). Environmental Monitoring and Assessment, 144: 301-313. doi: $\underline{10.1007 / \mathrm{s} 10661-007-9993-7}$

LUDWIG, J.A. \& REYNOLDS, J.F. (1988): Statistical Ecology: a Primer on Methods and Computing. John Wiley \& Sons, New York, 337 pp.

MACARTHUR, R.H. (1965): Patterns of spices diversity. Biological Revue, 40: 510-533. doi: $\underline{10.1111 / \text { j.1469-185X.1965.tb00815.x }}$

MagurRan, A.E. (1988): Ecological Diversity and its Measurement. Croom Helm Limited, London, 192 pp. doi: $10.1007 / 978-94-015-7358-0$

Majagi, S., NAIK, J. \& ChITRA, J. (2019): Zooplankton diversity and distribution in relation to water quality at Chikklingdalli Dam, Karnataka. International Journal of Research and Analytical Reviews, 6(1): 754-767.

MALAGI, S. \& ViJAYKUMAR, K. (2009): Ecology and abundance of zooplankton in Karanja reservoir. Environmental Monitoring and Assessment, 152: 451-458. doi: 10.1007/s10661-008-0329-Z

MALIK, D.S. \& PANWAR, P. (2016): Zooplankton diversity, species richness and their distribution pattern in Bhimtal Lake of Kumaun region, (Uttarakhand). Hydrology Current Research, 7(1): 17. doi: $\underline{10.4172 / 2157-7587.1000219}$

Manickam, N., Saravana Bhavan, P. \& SAnthaNAM, P. (2017): Seasonal variations in species composition and community structure of zooplankton in two perennial lakes of Coimbatore, Tamil Nadu, Southern India. Jourmal of Aquatic Research \& Marine Sciences, 1(1): 1-12.

Manickam, N., Saravana Bhavan, P., SANThanam, P. \& RAJAGOPAL, B. (2018): Impact of seasonal changes in zooplankton biodiversity in Ukkadam Lake, Coimbatore, Tamil Nadu, India, and potential future implications of climate change. The Journal of Basic and Applied Zoology, 79: 15. doi: $10.1186 / \mathrm{s} 41936-018-0029-3$

Masson, C.F. (1998): Biology Freshwater Pollution (3rd Edn). Harlow (Essex), Longman, 356 pp.

Michael, R.G. \& Sharma, B.K. (1988): Indian Cladocera (Crustacea: Branchiopoda: Cladocera). Fauna of India and adjacent countries Series, Zoological Survey of India. Calcutta, 262 pp.
Mishra, A., Chakraborty, S.K., JAISWAR, A.K., Sharma, A.P., DeshmuKhe, G., \& Mohan, M. (2010): Plankton diversity in Dhaura and Baigul reservoirs of Uttarakhand. Indian Journal of Fisheries, 57(3): 19-27.

NegI, V. \& PANT, M.C. (1983): Analysis of zooplankton community of Lake Khurpatal (Kumaun Himalaya). Tropical Ecology, 24: 271-282.

Osborne, A., Wanielista, P. \& Yousuf, A. (1976): Benthic fauna species diversity in six central Florida lakes in summer. Hydrobiologia, 48(2): 125-129. doi: 10.1007/BF00040164

Paulose, P.V. \& MAHeshwari, K. (2008): Seasonal variation in zooplankton community structure of Ramgarh Lake, Jaipur, Rajasthan. In. SENGUPTA, M \& DALWANI, R. (Eds.) Proceeding of Taal 2007, The $12^{\text {th }}$ World Lake Conference, p. 82-87.

RAINA, H.S. \& VASS, K.K. (1993): Distribution and species composition of zooplankton in Himalayan ecosystems. Internationale Revue der gesamten Hydrobiologie und Hydrographie, 78(2): 295-307. doi: 10.1002/iroh.19930780214

RAJASHEKHAR, M., ViJaYKumar, K. \& ParVeEn, Z. (2009): Zooplankton diversity of three freshwater lakes with relation to trophic status, Gulbarga district, North-East Karnataka, South India. International Journal of Systems Biology, 1(2): 32-37.

RAMALINGAPPA, A., RAJASHEKAR, M. \& VIJAYKUMAR, K. (2015): Zooplankton diversity in Heroor reservoir, Kalaburagi district, Karnataka. International Research Journal of Emerging Trends in Multidisciplinary, 1(8): 18-31.

SAGER, R.E. \& HASLER, A.D. (1969): Species diversity in lacustrine phytoplankton I. The components of the index of diversity from Shannon's formula. American Naturalist, 103: 51-59. doi: 10.1086/282581

SEGERS, H. (2008): Global diversity of rotifers (Rotifera) in freshwater. Hydrobiologia, 595: 49-59. doi: 10.1007/s10750-007-9003-7

ShaH, J.A., PANDit, A.K. \& Mustafa ShaH, G. (2017): Rotifer community in relation to limnological characteristics of Wular lake in Kashmir Himalaya. Ceylon Journal of Science, 46(2): 4957. doi: $10.4038 /$ cjs.v46i2.7429

SHARMA, B.K. (1983): The Indian species of the genus Brachionus (Eurotatoria: Monogononta: Brachionidae). Hydrobiologia , 104: 31-39. doi: $\underline{10.1007 / B F 00045949}$ 
SHARMA, B.K. (1995): Limnological studies in a small reservoir in Meghalaya (N. E. India). TIMOTIUS, K.H. \& GolTENBOTH, F. (Eds.) Tropical Limnology, Vol. II. Satya Wacana Christian University Press, Salatiga, Indonesia, p. 187-197.

SHARMA, B.K. (1998): Freshwater Rotifers (Rotifera: Eurotatoria). Fauna of West Bengal, State Fauna Series, 3(11): 341-461.

SHARMA, B.K. (2011a): Zooplankton communities of Deepor Beel (a Ramsar site), Assam (N. E. India): ecology, richness, and abundance. Tropical Ecology, 52(3): 293-302.

SHARMA, B.K. (2011b): Zooplankton diversity of two floodplain lakes (pats) of Manipur, northeast India. Opuscula Zoologica Budapest, 42(2): 185-197.

SHARMA, B.K. \& BhATTARAI, S. (2005): Hydro-biological analysis of a peat bog with emphasis on its planktonic diversity and population dynamics in Bumdeling Wildlife Sanctuary: eastern Bhutan. Limnology, 6: 183-187. doi: $\underline{10.1007 / \mathrm{s} 10201-005-0157-6}$

SHARMA, B.K. \& HATIMURIA, M.K. (2017): Zooplankton diversity of three floodplain lakes (beels) of the Majuli River Island, Brahmaputra river basin of Assam, northeast India. Journal of Aquaculture and Marine Biology, 6(1): 00144.

ShARMA, B.K. \& Hussain, MD. (2001): Abundance and ecology of Zooplankton in a tropical floodplain lake, Assam (N. E. India). Ecology, Environment \& Conservation, 7(4): 397-403.

SHARMA, B.K. \& LYNGSKOR, C. (2003): Plankton communities of a subtropical reservoir of Meghalaya (N. E. India). The Indian Journal of Animal Sciences, 73(2): 209-215.

SHARMA, B.K. \& LYNGDOH, R.M (2004): Zooplankton communities of Umiam reservoir, Meghalaya (N. E. India): composition, abundance and ecology. The Indian Journal of Animal Sciences, 74(6): 681-685.

SHARMA, B.K. \& NOROH, N. (2020): Zooplankton diversity of three floodplain lakes of the DibruSaikhowa Biosphere reserve, upper Assam, northeast India. International Journal of Aquatic Biology, 8(1):18-34. doi: 10.22034/ijab.v8i1.730

SHARMA, B.K. \& PACHUAU, L (2013): Zooplankton diversity of a sub-tropical reservoir of Mizoram, Northeast India. Opuscula Zoologica Budapest, 44(1): 47-60.
SHARMA, B.K., POU, K.R.S. \& SHARMA S. (2016): Rich rotifer assemblage (Rotifera: Eurotatoria) of a sub-tropical wetland of Meghalaya, northeast India: ecosystem diversity and interesting features. International Journal of Aquatic Biology, 4(3): 179188.

SHARMA, B.K. \& SHARMA, S. (1999a): Freshwater Rotifers (Rotifera: Eurotatoria). Fauna of Meghalaya, State Fauna Series, 4(9): 11-161.

SHARMA, B.K. \& SHARMA, S. (1999b): Freshwat Cladocerans (Crustacea: Branchiopoda: Cladocera). Fauna of Meghalaya, State Fauna Series, 4(9): 469-550.

SHARMA, B.K. \& SHARMA, S. (2011): Zooplankton diversity of Loktak Lake, Manipur, India. Journal of Threatened Taxa, 3(5): 1745-1755.

SHARMA, B.K. \& SHARMA, S. (2012): Diversity of zooplankton of a tropical floodplain lake of the Brahmaputra river basin, Assam (Northeast India). Opuscula Zoologica Budapest, 43(2): 187-195.

SHARMA, R.C. \& KumARI, K. (2018): Seasonal variation in zooplankton community and environmental variables of sacred Lake Prashar Himachal Pradesh, India. International Journal of Fisheries and Aquatic Studies, 6(2): 207-213.

SHARMA, P.C. \& PANT, M.C. (1984): Structure of a littoral zooplankton community of two Kumaun lakes, (U.P.), India. Limnologica (Berlin), 16(1): $51-65$.

SHARMA, P.C. \& PANT, M.C. (1985): Species composition of zooplankton in two Kumaun Himalayan lakes (U. P., India). Archiv für Hydrobiologie, 102: $387-403$.

SHARMA, S. \& SHARMA, B.K. (2008): Zooplankton diversity in floodplain lakes of Assam. Records of the Zoological Survey of India, Occasional Paper, 290: 1-307.

SHARMILA, S.J. \& SHAMEEM, U. (2017): Zooplankton diversity indices and Seasonal variations in Meghadrigedda reservoir, Visakhapatnam, Andhra Pradesh, India. European Journal of Biotechnology and Bioscience, 5(1): 4-1.

SINGH, S. \& SHARMA, R.C. (2020): Zooplankton diversity and potential indicator species for assessment water quality of high altitude wetland, Dodi Tal of Garhwal Himalaya, India. Academia Arena, 12(5): 1-16. doi: $10.7537 /$ marsaaj120520.01 
SHIVASHANKAR, P. \& VENKATARAMANA G.V. (2013): Zooplankton diversity and their Seasonal variations of Bhadra Reservoir, Karnataka, India. International Research Journal of Environment Sciences, 2(5): 87-91.

SHWETANSHUMALA \& SHARMA, L.L. (2020): Diversity of zooplankton and their seasonal variation of diversity in the Nandeshwer Dam, Udaipur, Rajasthan (India). Journal of Entomology and Zoology Studies, 8(2): 1482-1484

SLADECEK, V. (1983): Rotifera as indicators of water quality. Hydrobiologia, 100: 169-201. doi: $\underline{10.1007 / \mathrm{BF} 00027429}$

SLATHIA, S. \& DUTTA, S.P.S. (2013): Hydrobiological study of a subtropical Shiwalik Lake, Jammu, J \& $\mathrm{K}$ (India). International Journal of Chemical, Environmental \& Biological Sciences, 1(1), 143-148.

Steinitz-Kannan, M., Colinvaux, P.A. \& Kannan, R. (1983): Limnological studies in Ecuador: 1. A survey of chemical and physical properties of Ecuadorian lakes. Archiv für hydrobiologie, Supplement, 65: 61-105.

THAKUR, R.K., JINDAL, R., SingH, U.B. \& AHLUWALIA, A.S. (2013): Plankton diversity and water quality assessment of three freshwater lakes of Mandi (Himachal Pradesh, India) with special reference to planktonic indicators. Environmental Monitoring and Assessment, 185: 8355-8373. doi: $10.1007 / \mathrm{s} 10661-013-3178-3$

TIWARI, R.B. \& ChHETRY, D.T. (2009): Diversity of Zooplanktons in Betna Wetland, Belbari, Morang. Our Nature, 7: 236-37.

TwIN, Y.Y. \& AUNG, S.M. (2019): Seasonal occurrence of zooplanktons at the pond of Botataung Pagoda, Botataung township, Yangon region, Myanmar. International Journal of Innovative Science and Research Technology, 4(5): 991-995.

WANI, I.A. \& SUBLA, B.A. (1995): Changes in rotifer abundance and composition in two lakes in the Kashmir Valley (Himalayas). Journal of Indian Institute of Science, 75: 699-705.

WHITTAKER, R.H. (1965): Dominance and diversity in land plant communities. Science, 147: 250-260. doi: $\underline{10.1126 / \text { science. } 147.3655 .250}$

WILHM, J.L. \& DORRIS, T.C. (1968): Biological parameters for water quality criteria. Bioscience, 18: 477-481. doi: $\underline{10.2307 / 1294272}$

Appendix I. Monthly variations in abundance (ind. $1^{-1}$ ) of zooplankton (Littoral region)

\begin{tabular}{|l|c|c|c|c|c|c|c|c|c|c|c|c|}
\hline Zooplankton $\downarrow$ Months $\rightarrow$ & $\mathrm{J}$ & $\mathrm{F}$ & $\mathrm{M}$ & $\mathrm{A}$ & $\mathrm{M}$ & $\mathrm{J}$ & $\mathrm{J}$ & $\mathrm{A}$ & $\mathrm{S}$ & $\mathrm{O}$ & $\mathrm{N}$ & $\mathrm{D}$ \\
\hline ROTIFERA & & & & & & & & & & & & \\
\hline Ascomorpha ovalis & 18 & 75 & 50 & 12 & 10 & 5 & 7 & 20 & 5 & 2 & 5 & 14 \\
\hline Asplanchna priodonta & 8 & 20 & 15 & 12 & 8 & 7 & 3 & 2 & 1 & 4 & 5 & 5 \\
\hline B. quadridentatus & 3 & 2 & 1 & 1 & 0 & 0 & 0 & 0 & 2 & 3 & 2 & 1 \\
\hline Euchlanis dilatata & 1 & 0 & 0 & 1 & 0 & 0 & 0 & 1 & 0 & 0 & 0 & 1 \\
\hline Collotheca ornata & 1 & 2 & 0 & 0 & 0 & 1 & 0 & 1 & 0 & 1 & 0 & 0 \\
\hline Conochilus unicornis & 10 & 8 & 6 & 5 & 2 & 2 & 5 & 10 & 8 & 2 & 2 & 2 \\
\hline Colurella obtusa & 3 & 2 & 0 & 0 & 0 & 1 & 0 & 0 & 0 & 0 & 0 & 0 \\
\hline Keratella cochlearis & 1 & 1 & 2 & 5 & 5 & 20 & 100 & 94 & 23 & 14 & 1 & 1 \\
\hline Lepadella ehrenbergi & 2 & 0 & 0 & 1 & 0 & 0 & 0 & 1 & 0 & 0 & 1 & 0 \\
\hline L. ovalis & 1 & 0 & 0 & 1 & 0 & 0 & 1 & 0 & 0 & 1 & 0 & 0 \\
\hline Lepadella patella & 2 & 0 & 3 & 0 & 1 & 0 & 0 & 1 & 0 & 0 & 0 & 0 \\
\hline Lecane bulla & 2 & 0 & 0 & 0 & 1 & 2 & 1 & 1 & 0 & 0 & 0 & 0 \\
\hline L. closterocerca & 2 & 1 & 1 & 0 & 0 & 2 & 2 & 3 & 2 & 1 & 1 & 2 \\
\hline L. curvicornis & 3 & 0 & 0 & 1 & 1 & 0 & 2 & 0 & 1 & 1 & 1 & 2 \\
\hline L. hornemanni & 2 & 0 & 0 & 0 & 0 & 2 & 0 & 0 & 0 & 0 & 1 & 0 \\
\hline L. leontina & 4 & 0 & 0 & 1 & 0 & 0 & 0 & 1 & 2 & 0 & 0 & 1 \\
\hline L. luna & 2 & 0 & 0 & 0 & 0 & 1 & 0 & 0 & 1 & 2 & 1 & 0 \\
\hline L. lunaris & 3 & 2 & 1 & 1 & 2 & 0 & 0 & 1 & 0 & 1 & 0 & 0 \\
\hline L. quadridentata & 1 & 0 & 0 & 0 & 1 & 0 & 0 & 1 & 0 & 1 & 0 & 0 \\
\hline
\end{tabular}




\begin{tabular}{|c|c|c|c|c|c|c|c|c|c|c|c|c|}
\hline L. stenroosi & 1 & 2 & 0 & 0 & 0 & 0 & 0 & 0 & 1 & 1 & 1 & 0 \\
\hline Macrochaetus collinsi & 1 & 0 & 0 & 0 & 0 & 1 & 1 & 0 & 0 & 0 & 0 & 0 \\
\hline Mytilina ventralis. & 2 & 2 & 1 & 0 & 0 & 2 & 2 & 1 & 1 & 0 & 0 & 1 \\
\hline Plationus patulus & 2 & 1 & 0 & 0 & 0 & 2 & 0 & 0 & 3 & 2 & 1 & 1 \\
\hline Platyias quadricornis & 2 & 0 & 0 & 0 & 1 & 1 & 0 & 0 & 0 & 0 & 0 & 0 \\
\hline Polyarthra vulgaris & 8 & 10 & 5 & 0 & 0 & 2 & 7 & 17 & 4 & 2 & 1 & 1 \\
\hline Pompholyx sulcata & 3 & 3 & 1 & 1 & 0 & 1 & 1 & 1 & 0 & 2 & 0 & 0 \\
\hline Testudinella patina & 2 & 0 & 0 & 1 & 2 & 1 & 0 & 0 & 2 & 0 & 1 & 2 \\
\hline Trichocerca cylindrica & 3 & 1 & 0 & 2 & 0 & 0 & 1 & 0 & 0 & 0 & 2 & 1 \\
\hline T. pusilla & 0 & 0 & 0 & 2 & 3 & 1 & 1 & 0 & 0 & 0 & 1 & 2 \\
\hline T. similis & 2 & 0 & 1 & 1 & 1 & 1 & 2 & 2 & 0 & 0 & 0 & 0 \\
\hline Trichotria tetractis & 1 & 0 & 1 & 0 & 1 & 0 & 0 & 0 & 1 & 0 & 0 & 1 \\
\hline \multicolumn{13}{|l|}{ CLADOCERA } \\
\hline Alona rectangula & 2 & 3 & 2 & 2 & 10 & 8 & 4 & 3 & 2 & 2 & 3 & 2 \\
\hline Bosmina longirostris & 10 & 8 & 7 & 5 & 3 & 2 & 2 & 3 & 3 & 2 & 3 & 2 \\
\hline Bosminopsis deitersi & 6 & 5 & 3 & 2 & 2 & 20 & 28 & 16 & 10 & 8 & 6 & 5 \\
\hline Ceriodaphnia cornuta & 5 & 3 & 5 & 6 & 8 & 5 & 2 & 2 & 4 & 7 & 9 & 10 \\
\hline Chydorus angustirostratus & 2 & 1 & 0 & 0 & 0 & 0 & 2 & 1 & 1 & 0 & 1 & 2 \\
\hline C. sphaericus & 6 & 8 & 10 & 10 & 8 & 8 & 3 & 4 & 7 & 12 & 2 & 9 \\
\hline Diaphanosoma excisum & 2 & 1 & 0 & 0 & 2 & 2 & 1 & 0 & 0 & 1 & 1 & 2 \\
\hline D. sarsi & 1 & 1 & 2 & 2 & 1 & 1 & 0 & 2 & 2 & 0 & 2 & 3 \\
\hline Karualona karua & 3 & 2 & 1 & 3 & 2 & 1 & 1 & 1 & 1 & 0 & 0 & 2 \\
\hline Scapholeberis kingi & 3 & 2 & 1 & 1 & 1 & 1 & 3 & 3 & 0 & 0 & 2 & 3 \\
\hline \multicolumn{13}{|l|}{ COPEPODA } \\
\hline Mesocyclops leuckarti & 30 & 22 & 66 & 140 & 89 & 23 & 12 & 10 & 26 & 28 & 86 & 69 \\
\hline Microcyclops hyalinus & 8 & 11 & 12 & 22 & 10 & 6 & 5 & 5 & 9 & 12 & 10 & 9 \\
\hline Heliodiaptomus contortus & 2 & 3 & 3 & 1 & 0 & 1 & 2 & 1 & 1 & 0 & 2 & 2 \\
\hline H. viduus & 3 & 2 & 0 & 2 & 2 & 1 & 2 & 0 & 2 & 2 & 3 & 2 \\
\hline Nauplii & 12 & 22 & 27 & 32 & 18 & 15 & 9 & 24 & 10 & 16 & 20 & 14 \\
\hline \multicolumn{13}{|l|}{ RHIZOPODA } \\
\hline Arcella discoides & 6 & 3 & 1 & 0 & 1 & 1 & 1 & 0 & 2 & 0 & 1 & 1 \\
\hline A. hemispherica & 2 & 1 & 0 & 0 & 2 & 2 & 1 & 2 & 1 & 1 & 2 & 0 \\
\hline A. vulgaris & 0 & 2 & 0 & 1 & 0 & 0 & 0 & 2 & 1 & 0 & 0 & 1 \\
\hline Centropyxis aculeata & 1 & 0 & 0 & 0 & 1 & 0 & 0 & 0 & 0 & 1 & 0 & 0 \\
\hline C. ecornis & 1 & 0 & 0 & 0 & 0 & 0 & 0 & 1 & 0 & 0 & 0 & 0 \\
\hline Difflugia lebes & 2 & 0 & 2 & 1 & 2 & 1 & 1 & 0 & 0 & 1 & 1 & 0 \\
\hline D. oblonga & 1 & 1 & 0 & 0 & 0 & 0 & 0 & 1 & 0 & 0 & 0 & 1 \\
\hline Euglypha laevis & 1 & 0 & 0 & 0 & 1 & 1 & 1 & 0 & 0 & 1 & 0 & 0 \\
\hline Trinema enchelys & 0 & 0 & 0 & 0 & 0 & 0 & 0 & 0 & 1 & 0 & 0 & 1 \\
\hline OSTRACODA & 0 & 0 & 2 & 1 & 1 & 0 & 1 & 0 & 1 & 0 & 0 & 0 \\
\hline ROTIFERA & 96 & 132 & 88 & 48 & 39 & 55 & 136 & 158 & 57 & 40 & 27 & 38 \\
\hline CLADOCERA & 40 & 34 & 31 & 31 & 37 & 48 & 46 & 35 & 30 & 32 & 29 & 40 \\
\hline COPEPODA & 55 & 60 & 108 & 197 & 119 & 46 & 30 & 40 & 48 & 58 & 121 & 96 \\
\hline RHIZOPODA & 14 & 7 & 3 & 2 & 7 & 5 & 4 & 6 & 5 & 4 & 4 & 4 \\
\hline OSTRACODA & 0 & 0 & 2 & 1 & 1 & 0 & 1 & 0 & 1 & 0 & 0 & 0 \\
\hline ZOOPLANKTON & 205 & 233 & 232 & 279 & 203 & 154 & 217 & 239 & 141 & 134 & 181 & 178 \\
\hline
\end{tabular}


Appendix II. Monthly variations in abundance (ind. ${ }^{-1}$ ) of zooplankton (Limnetic region)

\begin{tabular}{|c|c|c|c|c|c|c|c|c|c|c|c|c|}
\hline Zooplankton $\downarrow \quad$ Months $\rightarrow$ & $\mathrm{J}$ & $\mathrm{F}$ & $\mathrm{M}$ & A & $\mathrm{M}$ & $\mathrm{J}$ & $\mathrm{J}$ & $\mathrm{A}$ & $\mathrm{S}$ & $\mathrm{O}$ & $\mathrm{N}$ & $\mathrm{D}$ \\
\hline \multicolumn{13}{|l|}{ ROTIFERA } \\
\hline Ascomorpha ovalis & 0 & 10 & 30 & 33 & 50 & 20 & 14 & 50 & 47 & 9 & 10 & 45 \\
\hline Asplanchna priodonta & 4 & 45 & 56 & 32 & 20 & 15 & 2 & 4 & 5 & 6 & 5 & 8 \\
\hline Brachionus rubens & 2 & 0 & 0 & 1 & 0 & 0 & 1 & 1 & 0 & 0 & 1 & 0 \\
\hline B. quadridentatus & 0 & 2 & 0 & 0 & 0 & 1 & 0 & 0 & 1 & 0 & 0 & 0 \\
\hline Collotheca ornata & 1 & 1 & 2 & 0 & 0 & 1 & 0 & 1 & 3 & 2 & 0 & 1 \\
\hline Colurella obtusa & 0 & 2 & 0 & 0 & 0 & 0 & 1 & 0 & 0 & 0 & 1 & 0 \\
\hline Conochilus unicornis & 5 & 7 & 10 & 190 & 57 & 40 & 33 & 30 & 12 & 15 & 20 & 10 \\
\hline Euchlanis dilatata & 2 & 0 & 1 & 1 & 0 & 0 & 0 & 0 & 0 & 0 & 0 & 1 \\
\hline Keratella cochlearis & 2 & 5 & 9 & 12 & 30 & 42 & 90 & 210 & 87 & 56 & 15 & 9 \\
\hline Lepadella patella & 1 & 0 & 9 & 0 & 1 & 0 & 0 & 0 & 1 & 0 & 0 & 0 \\
\hline Lecane bulla & 2 & 0 & 1 & 0 & 0 & 0 & 1 & 1 & 0 & 0 & 0 & 1 \\
\hline L. curvicornis & 0 & 2 & 0 & 1 & 1 & 0 & 1 & 0 & 0 & 1 & 1 & 0 \\
\hline L. leontina & 2 & 0 & 1 & 0 & 0 & 0 & 1 & 0 & 0 & 0 & 1 & 1 \\
\hline L. luna & 1 & 0 & 0 & 0 & 1 & 0 & 0 & 0 & 2 & 0 & 0 & 0 \\
\hline L. lunaris & 0 & 0 & 1 & 2 & 1 & 0 & 0 & 1 & 0 & 1 & 0 & 0 \\
\hline L. stenroosi & 0 & 1 & 0 & 0 & 0 & 1 & 0 & 0 & 0 & 0 & 1 & 0 \\
\hline Plationus patulus & 2 & 1 & 0 & 0 & 0 & 0 & 0 & 0 & 0 & 1 & 0 & 0 \\
\hline Polyarthra vulgaris & 5 & 8 & 10 & 8 & 12 & 30 & 10 & 9 & 8 & 6 & 10 & 8 \\
\hline Pompholyx sulcata & 3 & 2 & 5 & 1 & 8 & 12 & 6 & 1 & 0 & 2 & 0 & 2 \\
\hline Testudinella patina & 2 & 0 & 0 & 0 & 0 & 0 & 0 & 0 & 1 & 1 & 1 & 0 \\
\hline Trichocerca cylindrica & 2 & 0 & 0 & 1 & 0 & 0 & 0 & 1 & 0 & 0 & 0 & 1 \\
\hline T. similis & 1 & 0 & 2 & 3 & 5 & 8 & 2 & 6 & 2 & 1 & 0 & 1 \\
\hline Trichotria tetractis & 1 & 1 & 0 & 0 & 0 & 0 & 1 & 0 & 0 & 0 & 1 & 0 \\
\hline \multicolumn{13}{|l|}{ CLADOCERA } \\
\hline Alona rectangula & 2 & 0 & 1 & 3 & 1 & 0 & 1 & 0 & 1 & 0 & 0 & 1 \\
\hline Bosmina longirostris & 3 & 2 & 1 & 1 & 5 & 6 & 1 & 2 & 4 & 2 & 5 & 3 \\
\hline Bosminopsis deitersi & 2 & 5 & 3 & 6 & 8 & 15 & 8 & 12 & 6 & 3 & 2 & 2 \\
\hline Ceriodaphnia cornuta & 2 & 3 & 0 & 2 & 3 & 5 & 0 & 2 & 3 & 3 & 0 & 2 \\
\hline Chydorus angustirostratus & 0 & 1 & 0 & 0 & 0 & 0 & 0 & 1 & 0 & 1 & 0 & 0 \\
\hline C. sphaericus & 9 & 6 & 0 & 1 & 1 & 3 & 2 & 1 & 0 & 1 & 2 & 0 \\
\hline Diaphanosoma sarsi & 2 & 0 & 0 & 0 & 1 & 0 & 1 & 0 & 0 & 0 & 1 & 0 \\
\hline Karualona karua & 0 & 0 & 2 & 0 & 0 & 0 & 0 & 0 & 1 & 0 & 0 & 1 \\
\hline \multicolumn{13}{|l|}{ COPEPODA } \\
\hline Mesocyclops leuckarti & 36 & 15 & 42 & 90 & 70 & 55 & 20 & 10 & 5 & 5 & 7 & 16 \\
\hline Microcyclops hyalinus & 2 & 0 & 0 & 0 & 0 & 0 & 0 & 0 & 1 & 0 & 0 & 0 \\
\hline Heliodiaptomus contortus & 3 & 2 & 0 & 0 & 0 & 1 & 0 & 2 & 0 & 0 & 1 & 1 \\
\hline Nauplii & 10 & 18 & 8 & 32 & 20 & 33 & 29 & 17 & 5 & 3 & 8 & 5 \\
\hline \multicolumn{13}{|l|}{ OSTRACODA } \\
\hline Cypris sp. & 1 & 2 & 0 & 1 & 0 & 1 & 1 & 0 & 0 & 0 & 0 & 0 \\
\hline \multicolumn{13}{|l|}{ RHIZOPODA } \\
\hline Arcella discoides & 2 & 1 & 3 & 1 & 1 & 0 & 1 & 1 & 0 & 2 & 0 & 2 \\
\hline Arcella hemispherica & 1 & 1 & 0 & 0 & 0 & 0 & 0 & 0 & 2 & 0 & 1 & 0 \\
\hline A. vulgaris & 0 & 0 & 1 & 2 & 1 & 1 & 0 & 1 & 1 & 0 & 0 & 1 \\
\hline Centropyxis aculeata & 1 & 0 & 0 & 0 & 0 & 0 & 0 & 0 & 0 & 1 & 0 & 0 \\
\hline Difflugia lebes & 2 & 0 & 1 & 1 & 1 & 7 & 0 & 0 & 0 & 0 & 2 & 2 \\
\hline Euglypha laevis & 1 & 1 & 0 & 0 & 0 & 0 & 1 & 0 & 1 & 0 & 0 & 0 \\
\hline
\end{tabular}




\begin{tabular}{|l|c|c|c|c|c|c|c|c|c|c|c|c|}
\hline ROTIFERA & 38 & 87 & 137 & 285 & 186 & 170 & 163 & 315 & 169 & 101 & 67 & 88 \\
\hline CLADOCERA & 20 & 17 & 7 & 13 & 19 & 29 & 13 & 18 & 15 & 10 & 10 & 9 \\
\hline COPEPODA & 51 & 35 & 50 & 122 & 90 & 89 & 49 & 29 & 11 & 8 & 16 & 22 \\
\hline RHIZOPODA & 7 & 3 & 5 & 4 & 3 & 8 & 2 & 2 & 4 & 3 & 3 & 5 \\
\hline OSTRACODA & 1 & 2 & 0 & 1 & 0 & 1 & 1 & 0 & 0 & 0 & 0 & 0 \\
\hline ZOOPLANKTON & 117 & 144 & 199 & 425 & 298 & 297 & 228 & 364 & 199 & 122 & 96 & 124 \\
\hline
\end{tabular}

